\title{
VOLKMANN'S CONTRACTURE: TREATMENT BY EXCISION OF THE INFARCT
}

\author{
H. J. SEDdon, London, England \\ From the Institute of Orthopaedics
}

The purpose of this paper is to describe a method of treatment of Volkmann's contracture which is based on a conception so simple as to be self-evident. No attempt will be made to discuss the etiology of the disorder, which was established with great precision and clarity by Griffiths (1940) and is now generally recognised to be an acute ischaemia almost invariably of arterial origin. Nothing will be said about prevention. However, I must refer to the morbid anatomy and histology of muscle and nerve ischaemia because the proper application of the treatment depends on the accurate assessment, clinically and at operation, of the extent and severity of the damage.

The lesion is a massive infarct.* The treatment to be described is, briefly, excision of all irreparably damaged muscle and nerve followed by such reconstructive procedures as may be required to minimise the deficiency.

\section{MATERIAL}

Although the method is more widely applicable, $f$ the discussion will be limited to the commonest form of ischaemic contracture, that affecting the forearm muscles. The cases described have been selected on account of their severity. It is only in such cases that excision is appropriate. I have omitted a number of cases of great severity in which the whole forearm was hopelessly damaged as a result of a proximal arterial lesion. Some were investigated in detail, but the data add nothing to what is discussed below, and reconstructive surgery had nothing to offer these unfortunate patients.

It will be observed from Table I that involvement of the main nerve trunks was frequent, in itself a sufficient indication of the gravity of the ischaemia. The first six patients were adults, all in the fighting services, who were sent to the Peripheral Nerve Injuries Centre at Oxford during the second world war. They were described in a paper by Holmes, Highet and Seddon (1944) in which evidence was presented to prove that the nerve lesions found in cases of severe ischaemia of the forearm were due to the initial ischaemia, not to the subsequent contracture of the damaged muscle. These patients were subjected to very detailed examination. The vascular lesion was investigated by oscillometry, arteriography and operative exploration. The muscles and nerves were also inspected and many pieces removed for histological examination. Although at that time we concluded that the nerve lesions were irreparable, it happens that the information obtained is now relevant to the treatment proposed. Thus there are six patients who were investigated but not treated, followed by a further ten in whom investigation was followed by more or less successful amelioration of the ischaemic damage.

\footnotetext{
* Only by this dogmatic brevity can one avoid entanglement in the labyrinthine discussions on the exact pathology of ischaemic contracture that have taken place in France. Those interested may consult Cahuzac and Jung (1946) who give a good summary of recent French work.

† We have used the method three times for ischaemia of the calf muscle. My colleague J. I. P. James has successfully excised ischaemic carpal interossei in three cases. However, the trouble in the hand is that the palmar interossei are usually more severely affected than the dorsal, and if the palmar interossei are excised the nerve supply to the dorsal muscles is destroyed.
} 
TABLE I

The Involvement of Muscle Groups and of Nerves in Sixteen Cases of Volkmann's Contracture

\begin{tabular}{|c|c|c|c|c|c|c|c|c|c|}
\hline \multirow{3}{*}{$\begin{array}{c}\text { Case } \\
\text { number }\end{array}$} & \multirow{3}{*}{$\begin{array}{l}\text { Reference } \\
\text { number }\end{array}$} & \multirow{3}{*}{$\begin{array}{c}\text { Age } \\
\text { (years) }\end{array}$} & \multirow{3}{*}{\multicolumn{2}{|c|}{ Injury }} & \multicolumn{5}{|c|}{ Ischaemic damage } \\
\hline & & & & & \multirow{2}{*}{\multicolumn{2}{|c|}{$\begin{array}{c}\text { Muscle } \\
\text { Flexors Extensors }\end{array}$}} & \\
\hline & & & & & & & Median & Ulnar & Radial \\
\hline 1 & G 24 & 60 & 1940. & $\begin{array}{l}\text { Fracture of surgical neck } \\
\text { of humerus, axillary } \\
\text { wound }\end{array}$ & ++ & + & ++ & ++ & \\
\hline 2 & B 21 & 31 & 1941. & $\begin{array}{l}\text { Fracture mid-shaft of } \\
\text { humerus }\end{array}$ & +++ & ++ & $+t$ & ++ & + \\
\hline 3 & C 1 & 35 & 1941. & $\begin{array}{l}\text { Fracture mid-shaft radius } \\
\text { and ulna }\end{array}$ & +++ & ++ & ++ & ++ & \\
\hline 4 & M 32 & 41 & 1941. & $\begin{array}{l}\text { Bomb wounds injuring } \\
\text { lower end humerus and } \\
\text { brachial artery }\end{array}$ & $++t$ & ++ & also dire & t injury & \\
\hline 5 & S 35 & 37 & 1942. & Colles's fracture & $+t$ & ++ & ++ & + & + \\
\hline 6 & G 58 & 26 & 1943. & $\begin{array}{l}\text { Fracture upper third } \\
\text { radius and ulna }\end{array}$ & + & $(+)$ & + & + & \\
\hline 7 & 16,988 & 9 & 1946. & Supracondylar fracture & $+t+$ & & ++ & ++ & \\
\hline 8 & $17,317 \times$ & 5 & 1947. & Supracondylar fracture & +++ & ++ & ++ & ++ & \\
\hline 9 & 644 & 5 & 1944. & $\begin{array}{l}\text { Comminuted fracture of } \\
\text { elbow }\end{array}$ & +++ & & $\begin{array}{l}\text { no evide } \\
\text { six }\end{array}$ & $\begin{array}{l}\text { nce of } d \\
\text { years late }\end{array}$ & $\begin{array}{l}\text { lamage } \\
\text { er }\end{array}$ \\
\hline 10 & 41,527 & 8 & 1939. & Supracondylar fracture & +++ & & ++ & ++ & \\
\hline 11 & 46,751 & 7 & 1951. & $\begin{array}{l}\text { Monteggia fracture-dislo- } \\
\text { cation }\end{array}$ & ++ & & + & $t$ & \\
\hline 12 & 55,873 & 6 & 1951. & Supracondylar fracture & ++ & & + & + & \\
\hline 13 & 62,449 & 29 & 1952. & $\begin{array}{l}\text { Prolonged compression } \\
\text { of forearm }\end{array}$ & + & & + & + & \\
\hline 14 & 70,344 & 5 & 1953. & Transcondylar fracture & +++ & & ++ & + & \\
\hline 15 & 100,878 & 11 & 1954. & Supracondylar fracture & +++ & ++ & ++ & ++ & \\
\hline 16 & 76,895 & 30 & 1954. & $\begin{array}{l}\text { Comminuted fracture } \\
\text { lower end of humerus }\end{array}$ & +++ & & ++ & + & \\
\hline
\end{tabular}

vol. 38 B, NO. 1, FEBRUARY 1956 


\section{MORBID ANATOMY}

The zone of damage differs considerably from the typical conical infarct seen in solid organs such as the lung or spleen. It differs both in shape and in the distribution of tissue change. When the distal part of the brachial artery goes into spasm as a result of severance, nipping or contusion, an ellipsoid zone of ischaemia is produced with its central point somewhere about the middle of the forearm (Figs. 1 to 3). The degree of damage is usually greatest at the centre (Table II), whereas at the periphery it may be comparatively slight, thanks to the collateral circulation. It is rare for the superficial muscles to be affected as

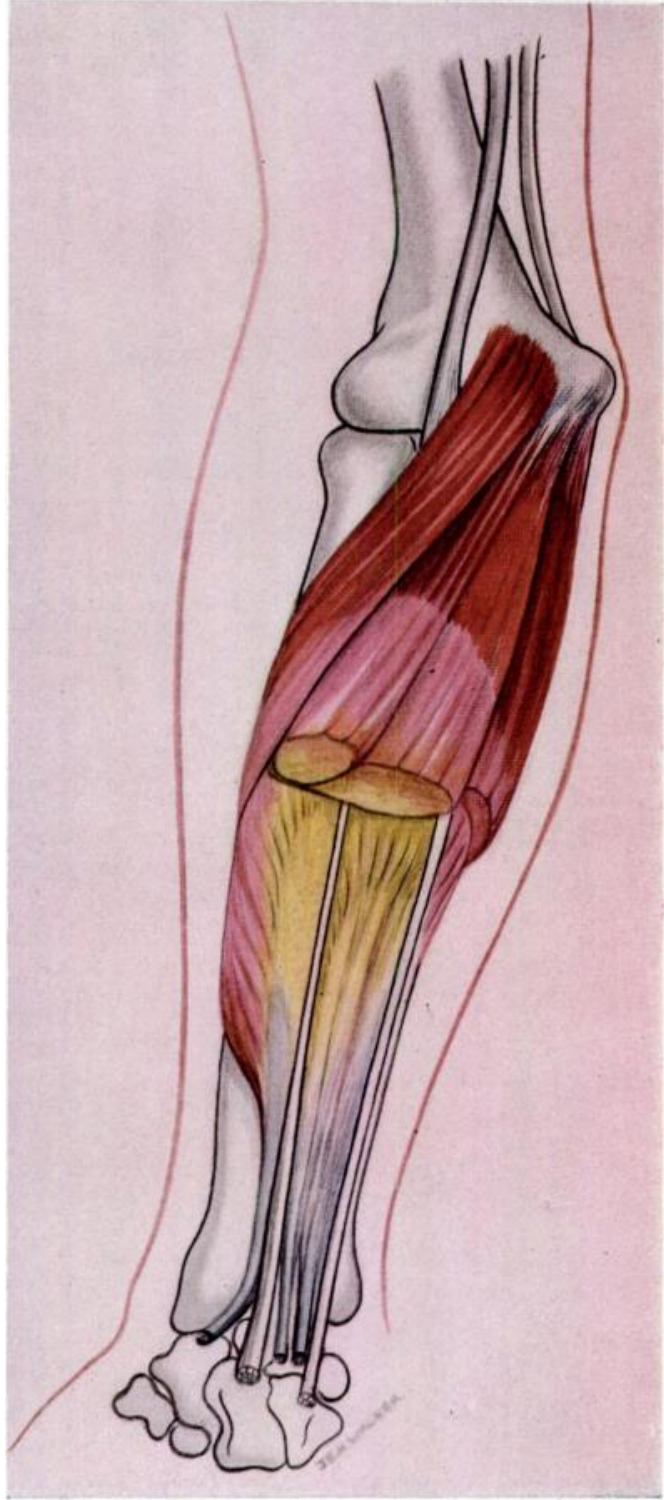

Fig. 1

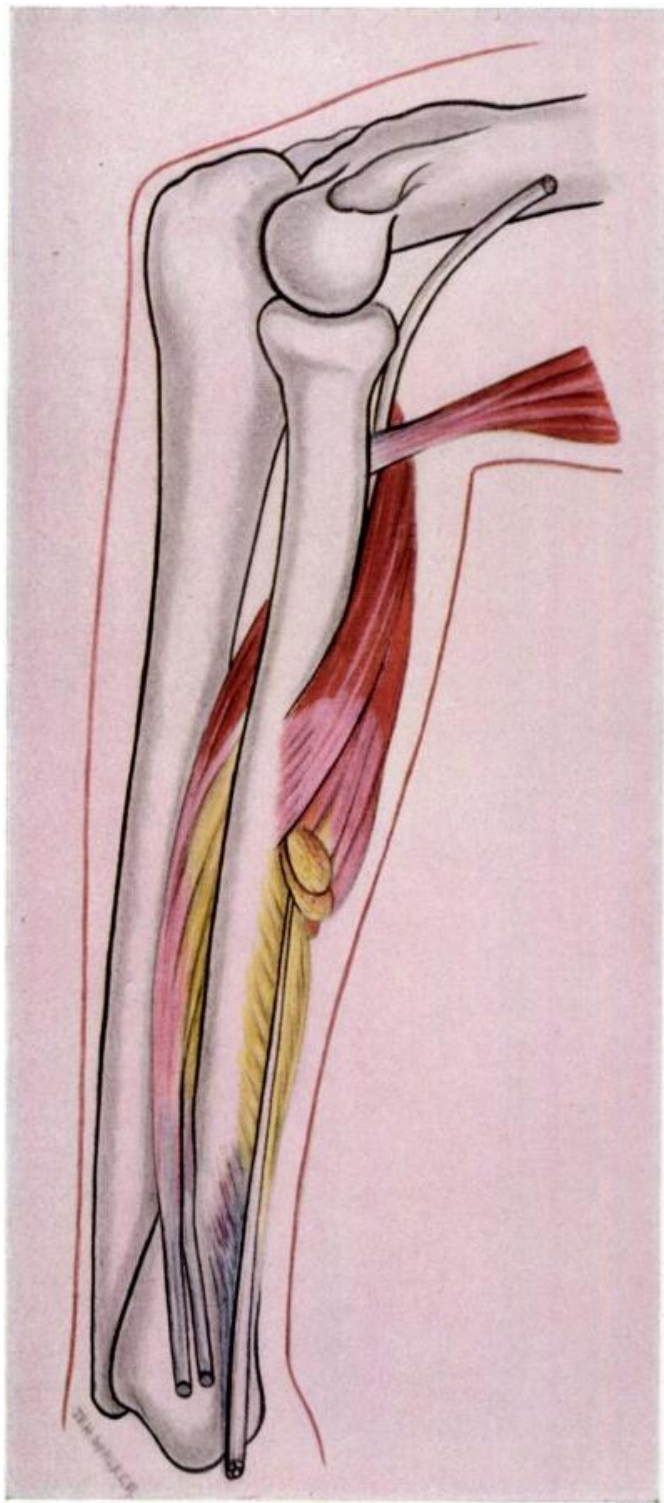

FIG. 2

Figure 1-A schematic drawing of the zone of ischaemia in Volkmann's paralysis of a right forearm. The yellow zone is that in which complete necrosis is commonly found and it may involve the median nerve. In the pink zone the muscle may be completely or partially fibrotic. Figure 2-A lateral view of a right forearm showing how the deep extensor muscles may be involved. 
much as those more deeply placed. Furthermore, a forearm muscle is often unequally affected throughout its length; its extremities may escape.

There are great variations. These depend on the level of the arterial lesion, no doubt too on the degree and duration of ischaemia and on the hazard of arterial spasm involving this or that branch of the brachial vascular tree-though neither of these factors is susceptible of investigation. There is yet another factor, though I have not been able to take account of it - the situation of the neurovascular hila of the long muscles, so elegantly described by Brash (1955).

What is so remarkable is that in spite of these variables there is indeed some sort of pattern. The ellipsoid zone of ischaemia has its axis somewhere near the anterior interosseous artery. The muscles that usually suffer most severely are the flexor digitorum profundus and the flexor pollicis longus which lie on either side of it. Moreover, if the extensor muscles are affected, the most vulnerable are those most deeply situated.

A main nerve trunk running through the centre of the ellipsoid zone of ischaemia will tend to suffer great damage. In one lying at the periphery the damage will be less severe. Thus the median nerve suffers more frequently and more severely than the ulnar nerve.

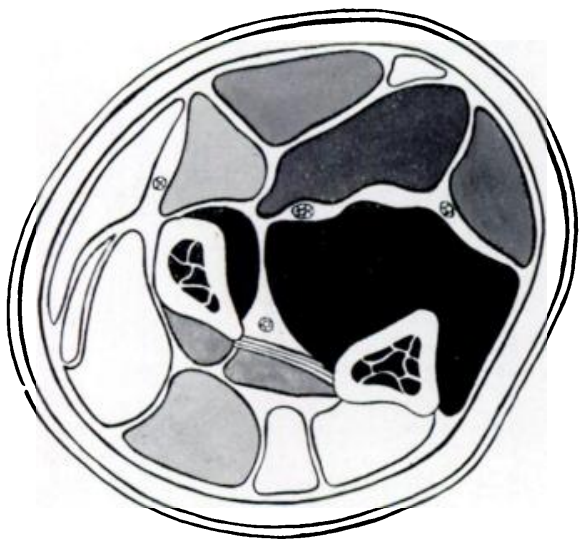

FIG. $3 a$

Figure $3 a$-The shading represents the degree of involvement of the various muscles. This diagram is based on the data given in Table II.

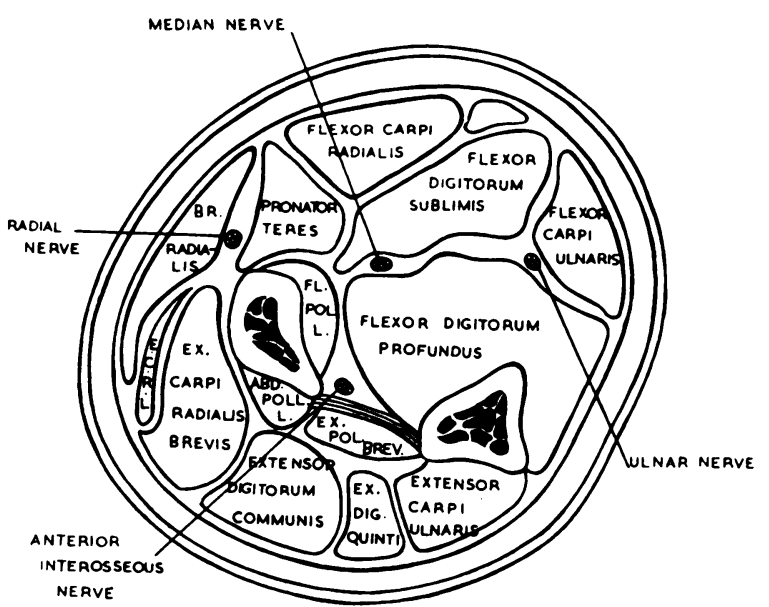

FIG. $3 b$

Figure $3 b$-Key to muscles, the plane of section being in the upper third of the forearm.

\section{Muscle}

a) Reversible damage - Le Gros Clark and Blomfield (1945) have shown experimentally that in the rabbit damage to muscle due to ischaemia may be reversible. Under favourable conditions the dead muscle fibres are removed and replaced by new ones which grow longitudinally along the surviving sarcolemmal tubes from the unaffected muscle above and below. In man some such process must occur more frequently than is realised. Anyone who has made even a cursory study of the histology of ischaemic contracture is familiar with the appearance of regeneration, usually abortive, at the periphery of the ischaemic zone (see Hughes 1948, Horn and Sevitt 1951, and Fig. 4). In Volkmann's ischaemia there is often at first a total paralysis of the forearm, but within two or three months the extensor muscles recover well and there may be some recovery in the flexors too. This recovery is most noticeable in the superficial muscles. Reference to spontaneous recovery will be made later in the paper.

VOL. 38 B, NO. 1, FEBRUARY 1956 


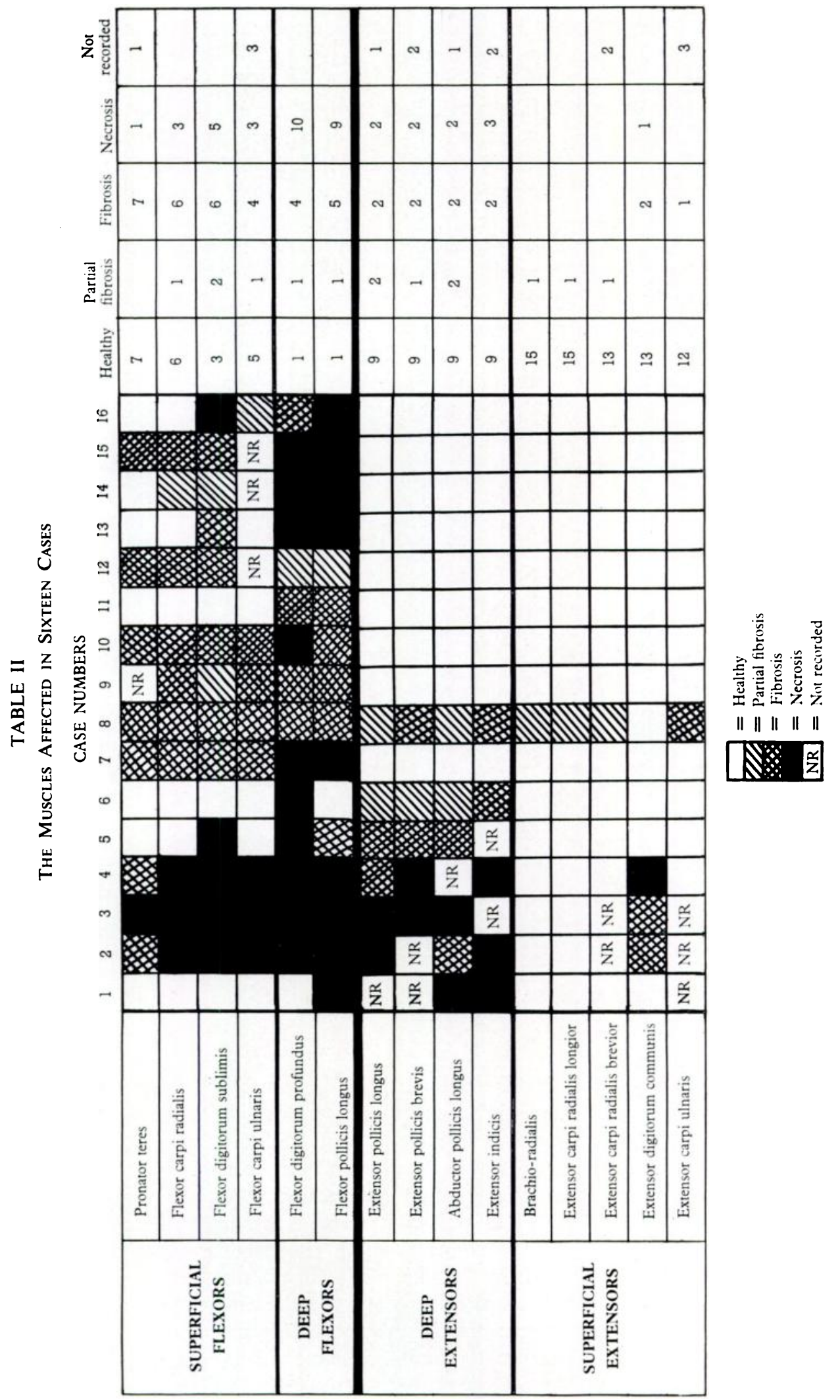

THE JOURNAL OF BONE AND JOINT SURGERY 


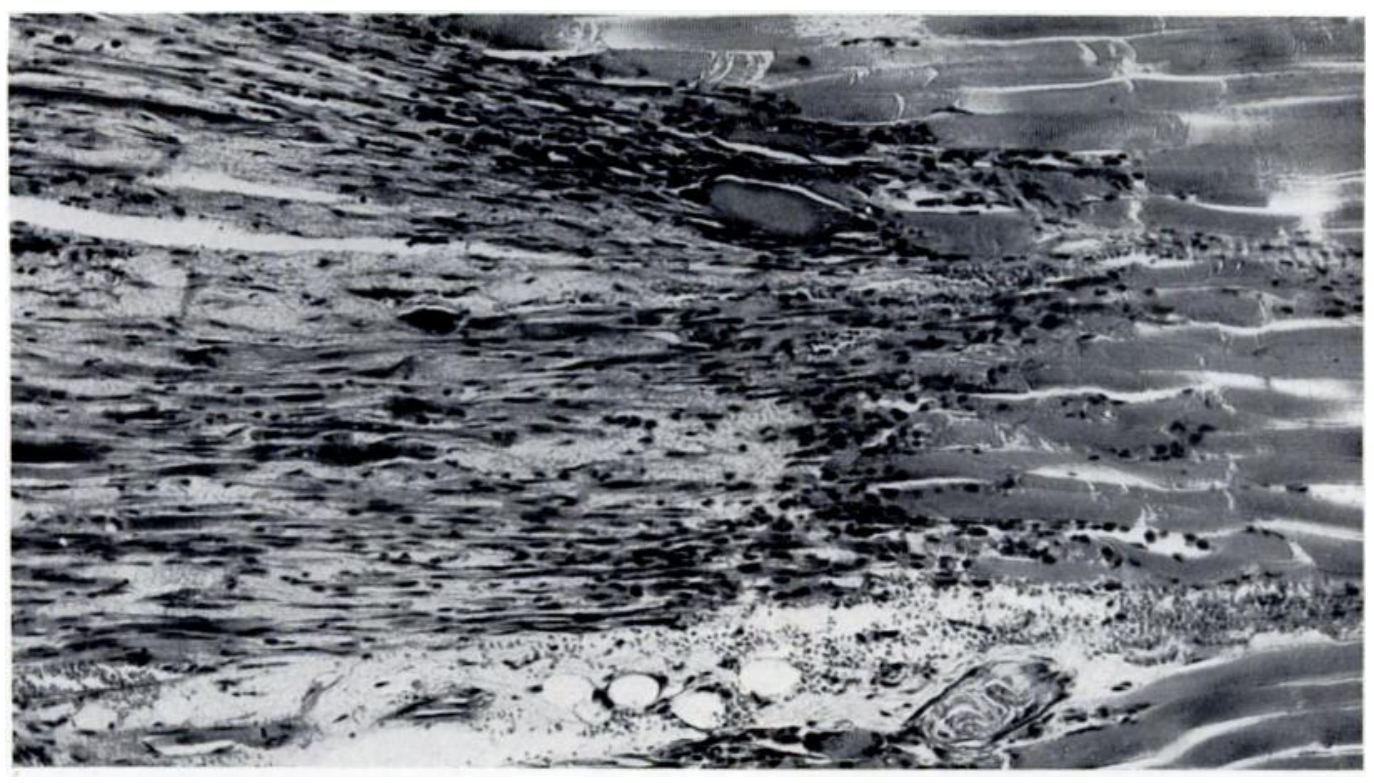

FIG. 4

The tissue adjacent to the necrotic muscle contains slender regenerating muscle fibres. $(145$.

b) Partially reversible damage -Some muscles show partial recovery but develop a contracture. They exhibit a certain pallor and, histologically, a diffuse fibrosis.

c) Irreversible damage - There is every gradation of fibrosis up to almost complete fibrous replacement of a muscle with little contractile tissue surviving (Figs. 5 and 6). The clinical manifestation is contracture and an absence of contractility. Lastly, a zone of muscle may undergo complete necrosis which leads to the most dramatic changes. The muscle is converted into a greenish-yellow pulpy mass, completely bloodless, which is easily scraped out with a spoon. Histological examination of this material confirms that it is necrotic (Fig. 7). Yet here again there is a gradation. There may be minute foci of necrosis in an otherwise completely fibrotic muscle (Fig. 8).

In a typical severe case the centre of the infarct is dead tissue. The zone of necrosis is surrounded by one in which necrosis and fibrosis occur together. Much of the necrotic material is removed by phagocytosis (Figs. 9 and 10). More peripherally the fibrosis is less pronounced and in the outermost zone there is reversible ischaemia.

\section{Nerve}

There are similar changes in the nerves which have been fully described by Holmes et al. (1944).

a) Reversible damage - Wallerian degeneration can occur as a result of mild ischaemia and it may be followed by the usual type of regeneration of fibres from the proximal healthy part of the nerve.

b) Irreversible damage - A nerve may undergo complete collagenisation in every respect comparable with total fibrosis of a muscle, and this process is irreversible. It is easily recognised histologically (Fig. 11) and is manifest at operation as a gross shrinkage of the nerve trunk, which may be less than a quarter of its normal diameter (Figs. 6, 12 and 13 ).

c) In the centre of a zone of total ischaemia a nerve may share in the massive necrosis (Fig. 7) and be converted into a dull yellow avascular structure which retains its axons and myelin sheaths simply because there is nothing to remove them.

VOL. 38 B, NO. 1, FEBRUARY 1956 


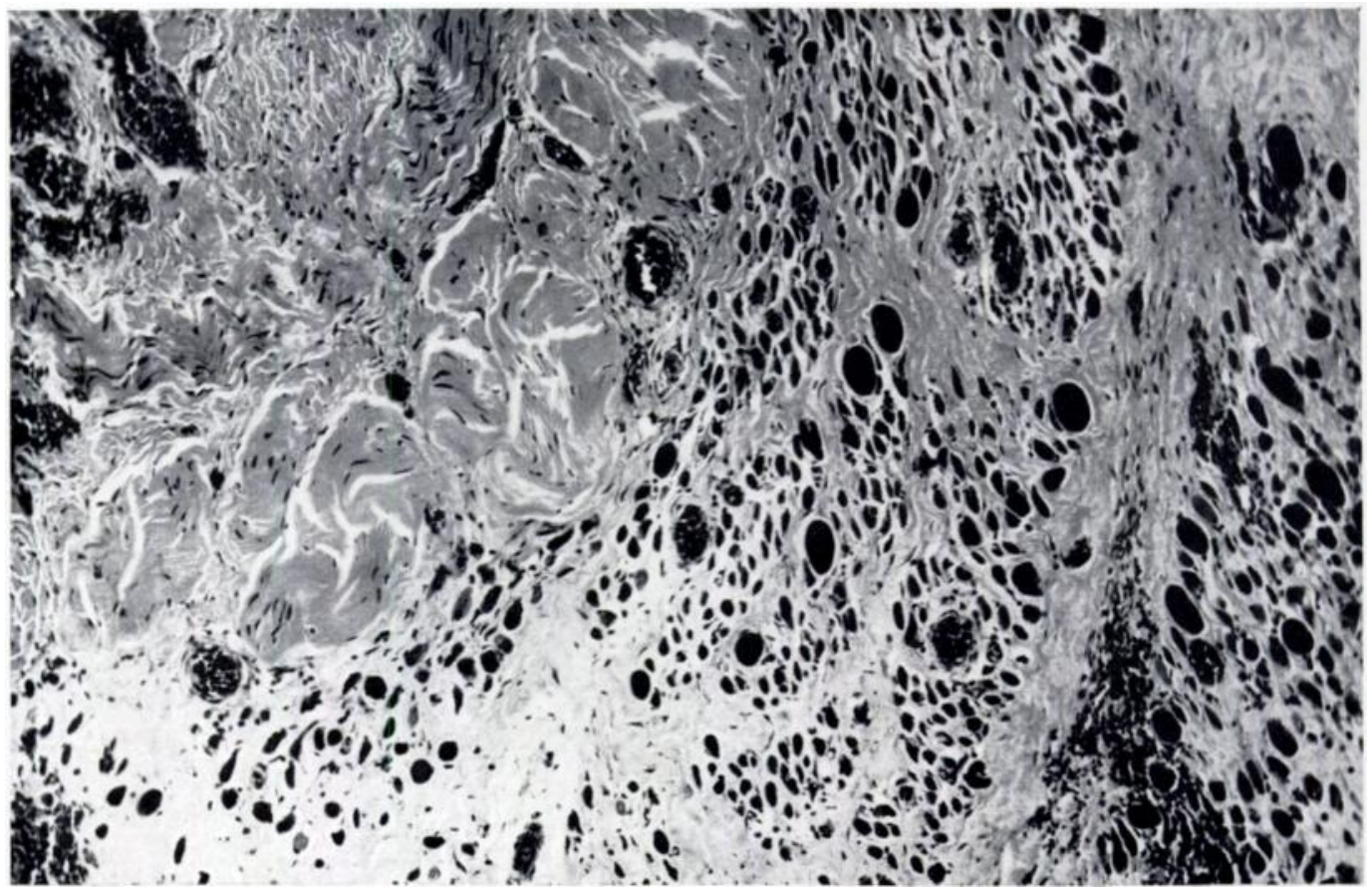

FIG. 5

Atrophy and fibrosis of non-necrotic muscle. ( $\times 145$.

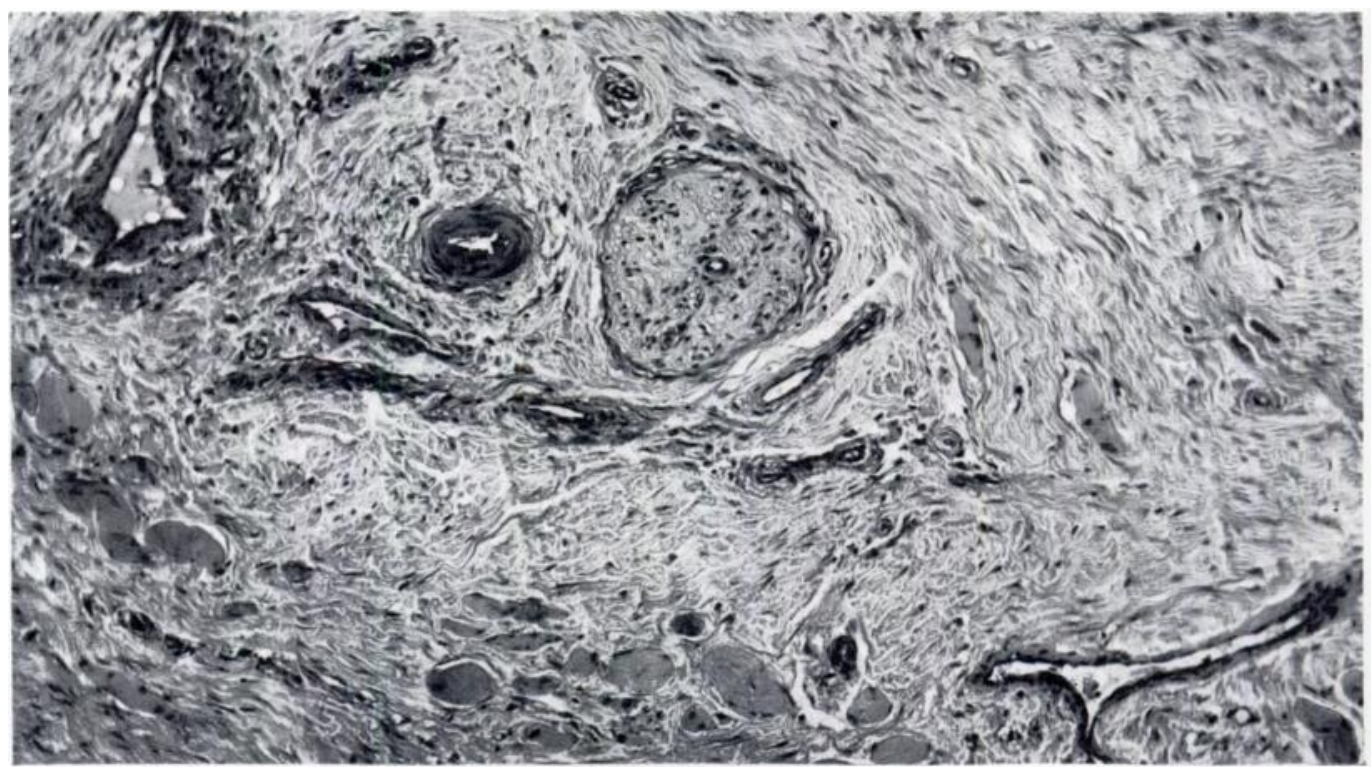

FIG. 6

An area of intensely fibrotic muscle. The muscle fibres included in the field are not necrotic. A small nerve bundle shows severe loss of myelinated fibres with some endoneurial fibrosis. $(\times 145$.) 


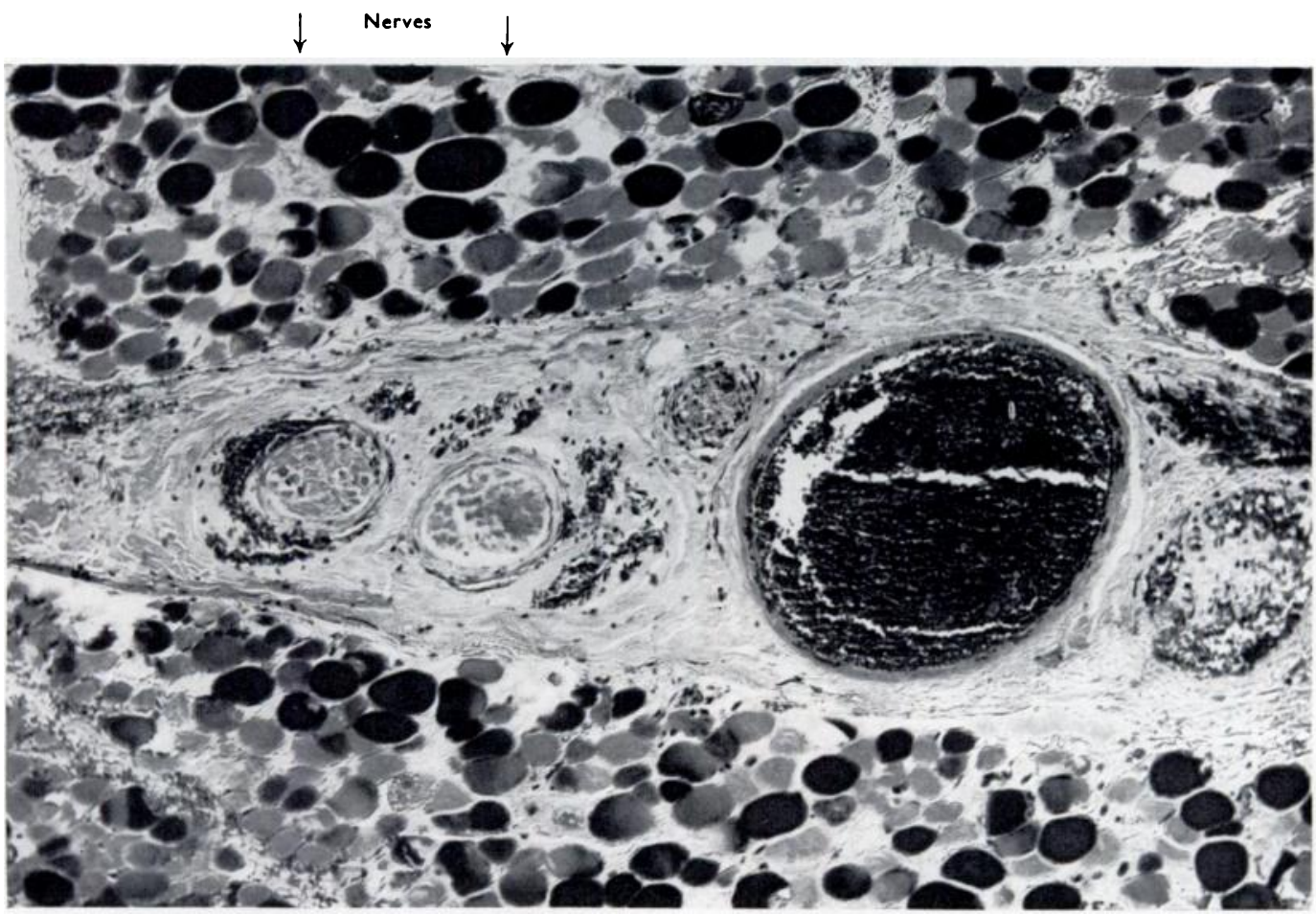

Fig. 7

The centre of a necrotic zone. Muscle fibres are all necrotic; note their variable staining reaction. The artery in the centre of the field is distended with blood clot and its wall is necrotic. Two nerve bundles are completely necrotic. The only persisting cells in this field are a few fibroblasts in the connective tissue surrounding the vessels and nerves. $(\times 145$. $)$

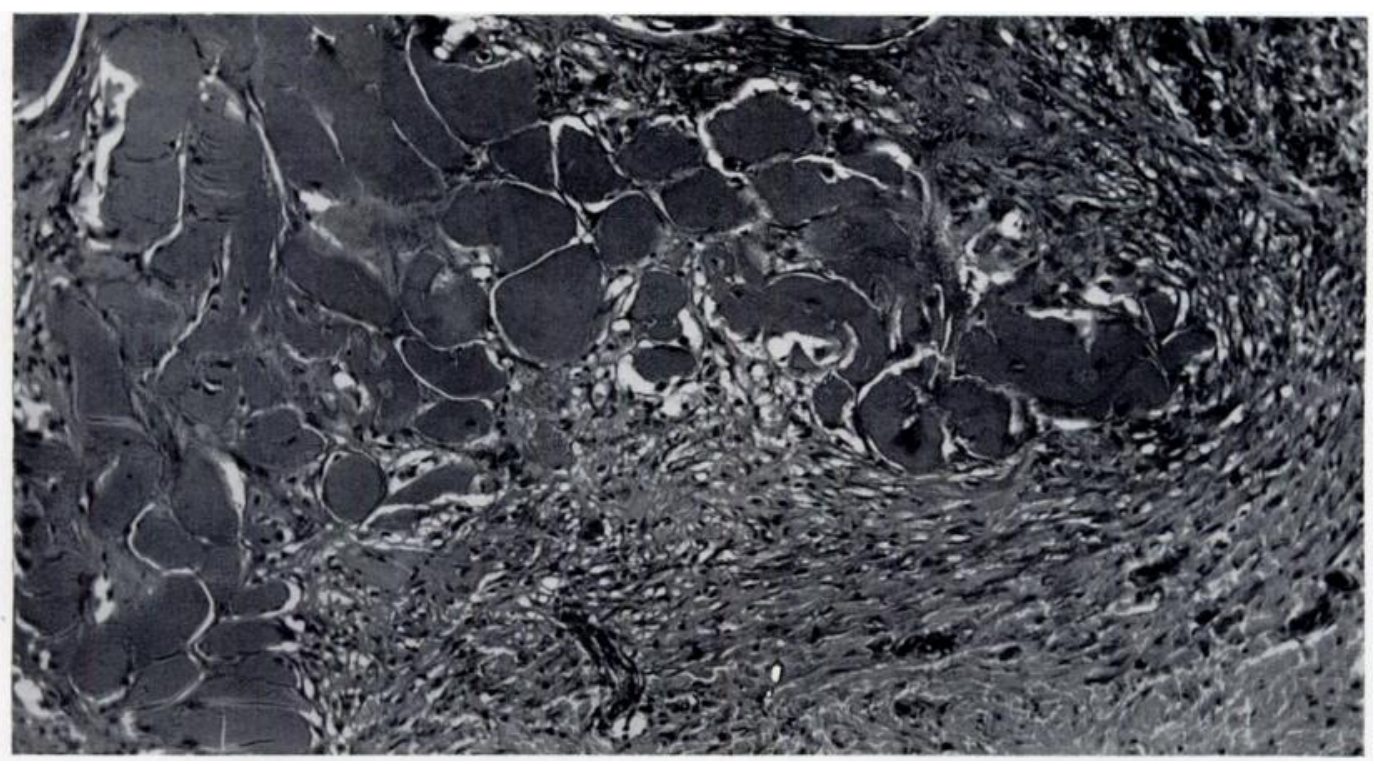

FIG. 8

An island of necrotic muscle fibres surrounded by newly formed tissue. $(\times 145$.) 


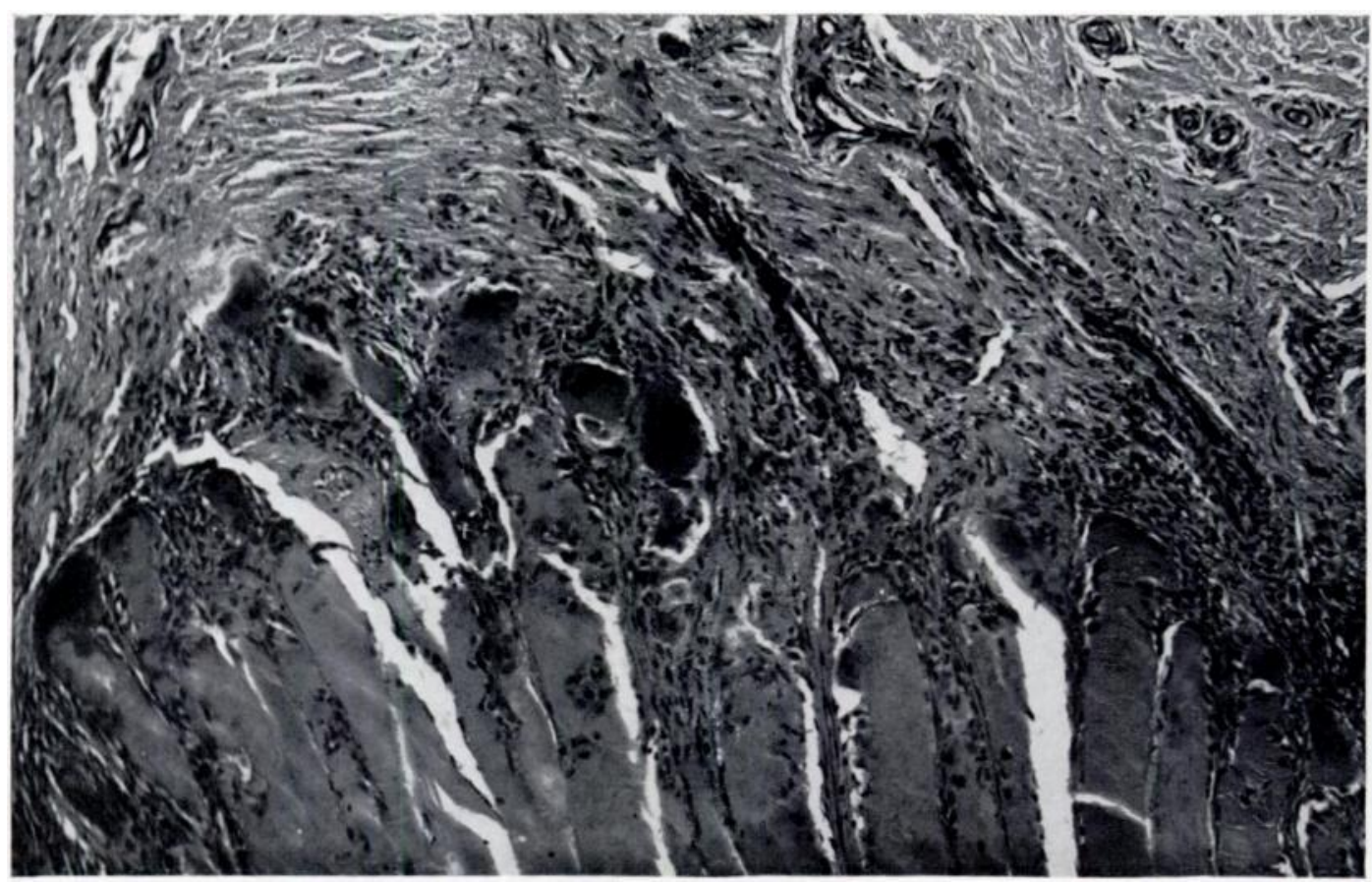

Fig. 9

Phagocytosis of the necrotic fibres by macrophages and by multinucleated giant cells. $(\times 145$.

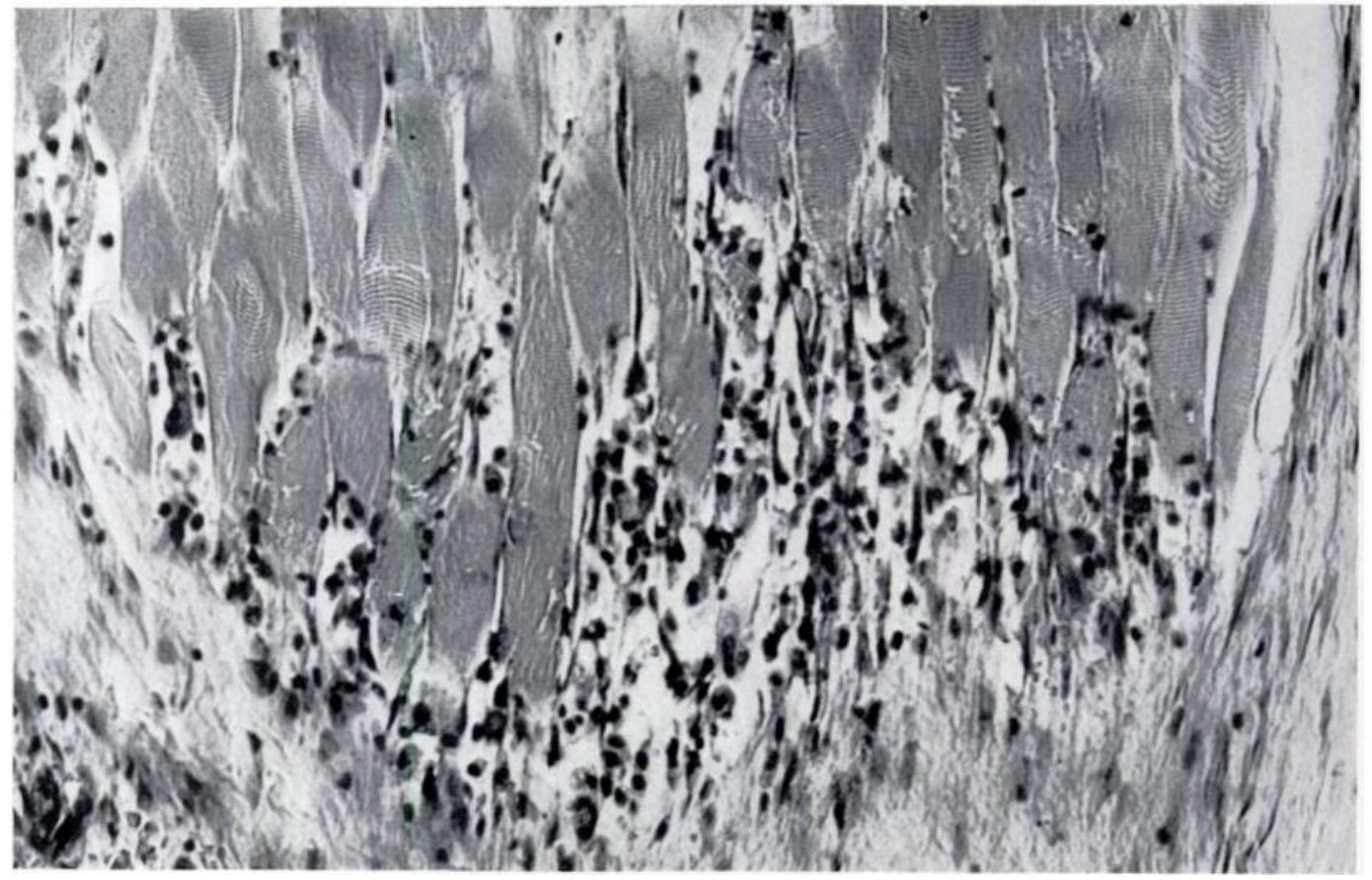

Fig. 10

Higher power view of area of phagocytosis. Note the accentuated cross-striation in the necrotic muscle. $(\times 255$. $)$ 

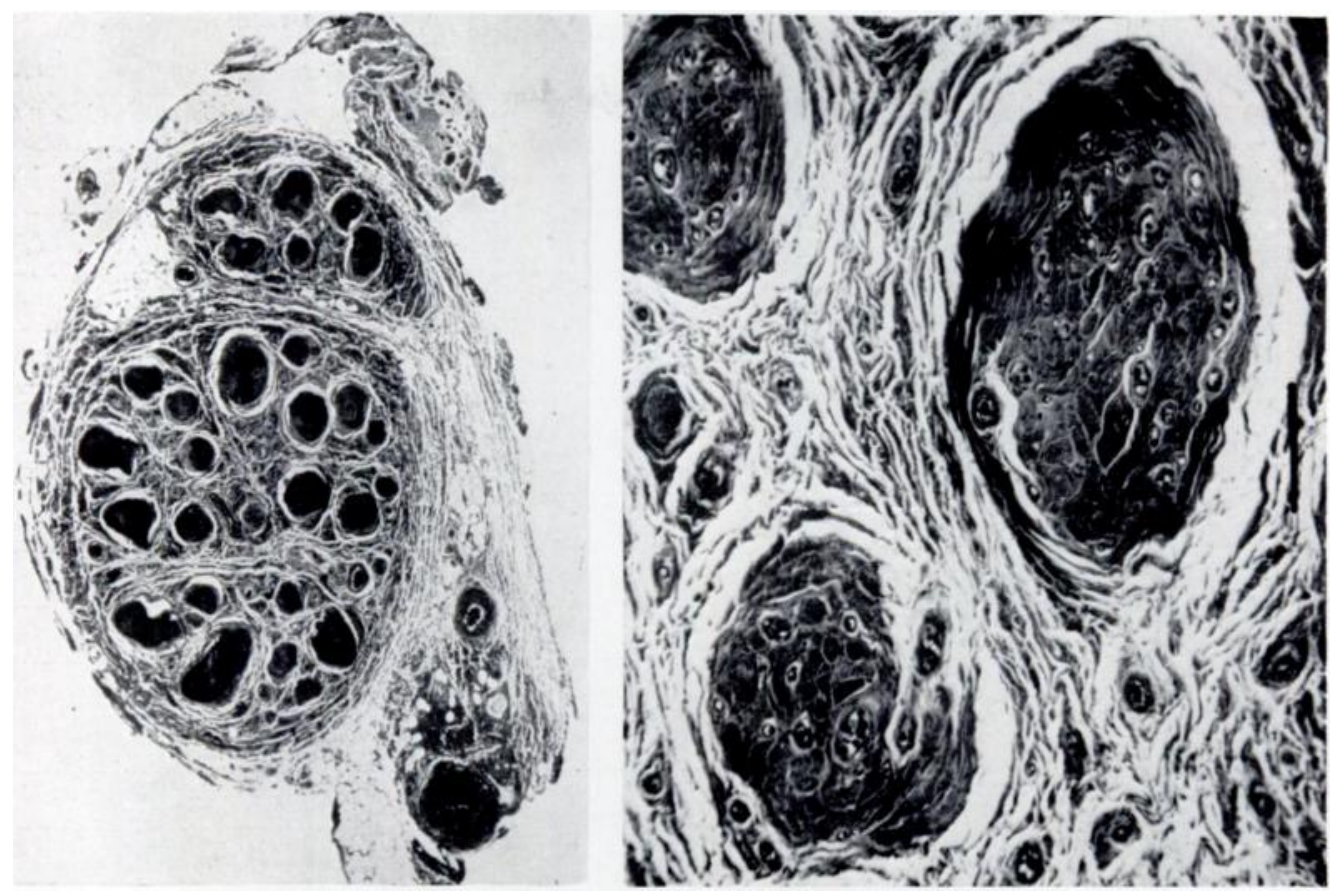

Fig. 11

Nerve bundles completely destroyed by interstitial collagenisation. Left, low magnification. Right, high magnification. The Schwann tubes are almost completely replaced by dense collagen. Magnifications not recorded.

\section{SPONTANEOUS RECOVERY AND CONSERVATIVE TREATMENT}

Excision of the infarct is an operation to be employed only in severe cases of Volkmann's ischaemia. Although the structural changes that are reversible are easily distinguishable pathologically from those that are not, the clinical distinction is difficult and one can make it only by waiting and watching.

Here is the case history of a boy on whom I twice decided to operate because of the great severity of the paralysis. On each occasion operation was postponed because just when the situation seemed very gloomy, he exhibited a little return of function. In the end recovery was excellent with only a minimal contracture.

C. C., a boy aged five years, suffered a lesion of the right brachial artery from a supracondylar fracture. Vigorous efforts to restore the circulation were unsuccessful. He developed paralysis of all muscles below the elbow and sensibility was lost in the median, ulnar and superficial radial areas. Recovery occurred as follows:

$a$ ) in the extensor group (Table III) it began on the fiftieth day and there was no "march" of recovery from the proximal to the distal muscles; $b$ ) in the flexor group recovery began on the eighty-seventh day and here again there was no regular proximal to distal progression; $c$ ) the intrinsic muscles of the hand, which were paralysed as a result of the nerve lesions and showed a reaction of denervation, began to recover much later, towards the 200th day; $d$ ) in the palm of the hand sensibility began to return on the 140th day.

Thus there were two phases of recovery; in the forearm muscles fairly early recovery, earlier in the extensors than in the flexors, and occurring at about the same rate in all muscles; and in the hand a late recovery, resembling that following an ordinary degenerative nerve lesion in that the rate was roughly one millimetre a day for sensory fibres and rather less for motor. The sensory recovery clearly exhibited a proximal to distal progression. In another similar case recovery began at three months and was well advanced by the fifth. 
TABLE III

The Progress of Spontaneous Recovery in Case C. C.

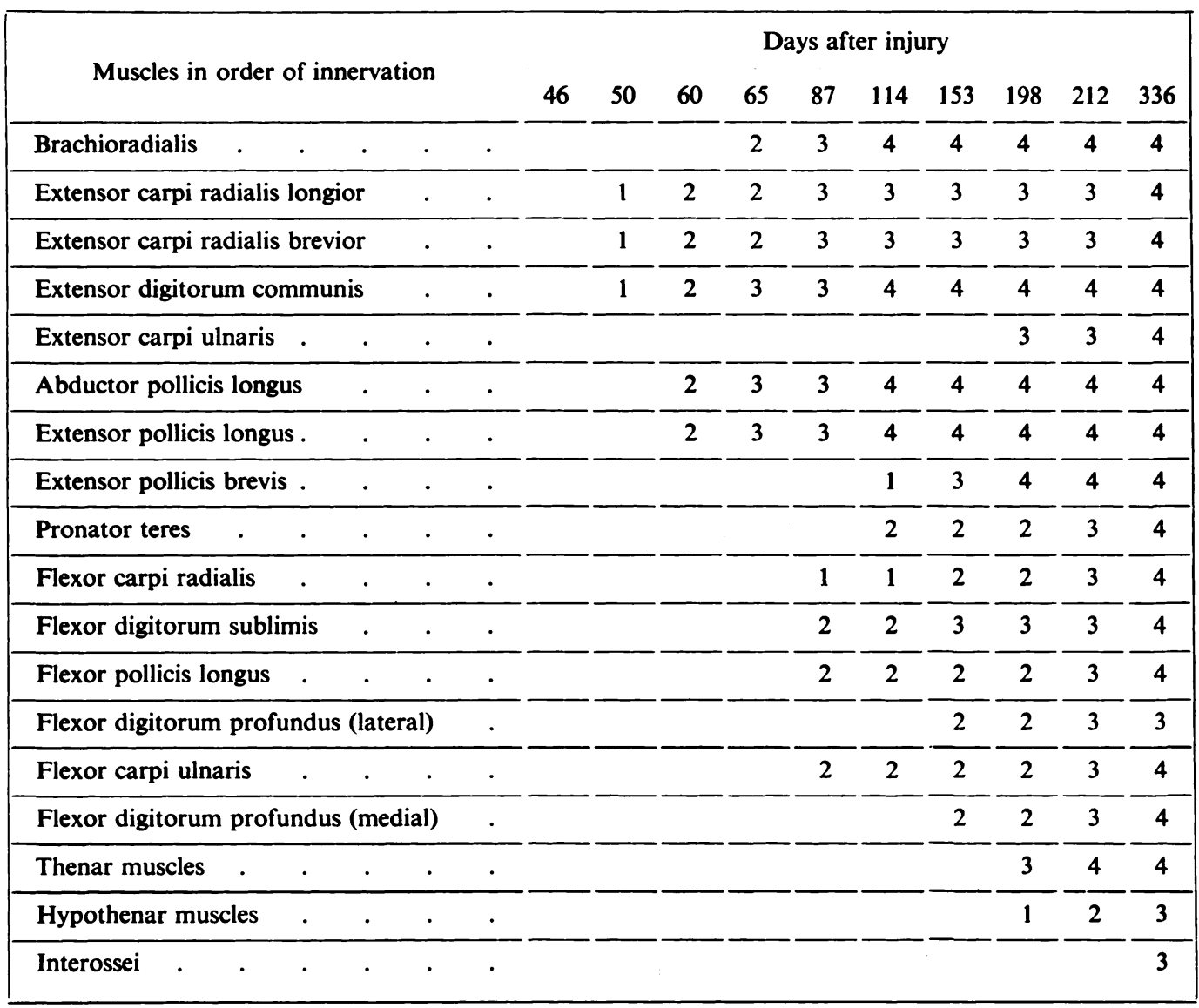

1-Flicker.

2-Movement only with gravity eliminated.

3-Movement against gravity but not against resistance. 4-Movement against gravity and resistance.

It is impossible to distinguish recovery of ischaemic muscle due to regeneration of muscle fibres from that due to regeneration of the nerve fibres they contain, but the pattern of the proximal recovery in the patient C. C., and perhaps its rate, suggests that it is the regeneration of the ischaemic muscle that sets the pace. Peripheral nervous tissue is manifestly less susceptible to ischaemia than muscle, and it is conceivable that in the relatively mild ischaemia suffered by $\mathrm{C}$. C. the small motor branches to the proximal muscles never underwent Wallerian degeneration, although the more peripheral parts of the large nerve trunks did so.

The important practical lesson to be learned is that one should wait for at least three months for evidence of spontaneous recovery in the forearm muscles before embarking on the drastic treatment proposed in this paper. During this time treatment should be limited to:

(a) splinting to minimise the contracture. The splint I have employed (Fig. 14), a refinement of one devised by Michel (1924), is very useful for this purpose; (b) movements of all joints: if mobility is lost the prognosis is very poor; $(c)$ if there is a nerve lesion, daily galvanic stimulation of the muscles of the hand (Jackson 1945, Jackson and Seddon 1945). 


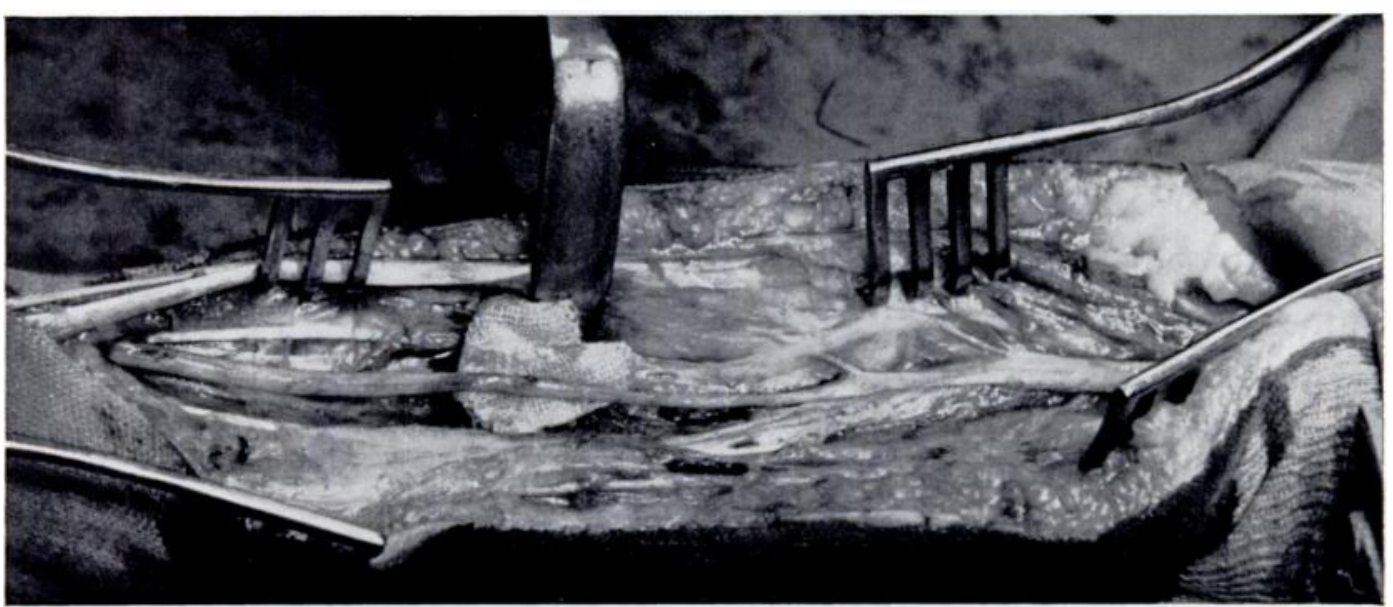

FIG. 12

Case 7-The median nerve. The proximal part is to the right and it will be seen that it gradually tapers to a narrow strand about a quarter the normal size. Then, just distal to the small swab, the nerve enlarges again though not to the same size as proximally. The narrow part is irreparably damaged. The broader distal part showed ordinary Wallerian degeneration. A nerve-pedicle graft was carried out in this case with an excellent result.

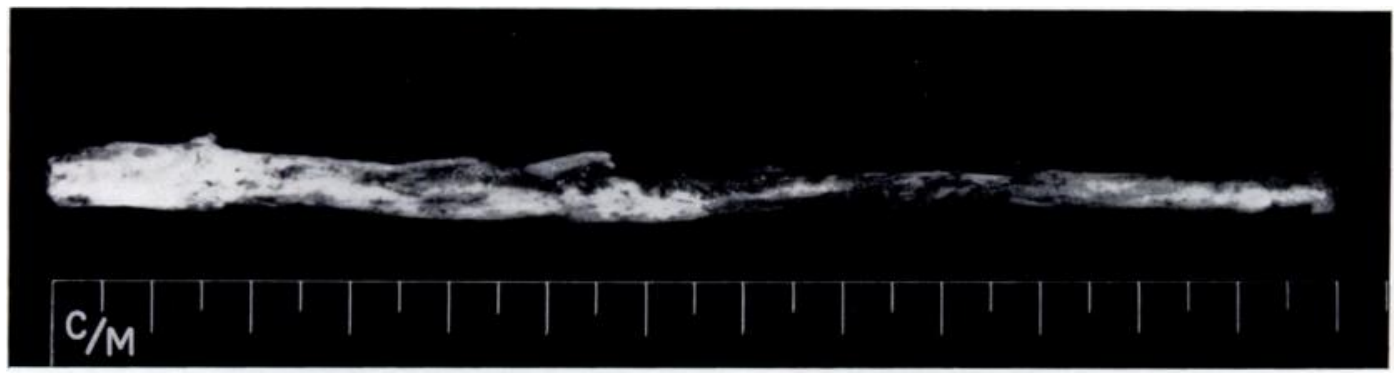

FIG. 13

Case 15-The excised segment of ischaemic nerve.

\section{THE EVOLUTION OF THE OPERATION}

The operations commonly employed for the relief of Volkmann's contracture are summarised in Table IV. They all have shortcomings and there is no recognised remedy for severe ischaemic nerve lesions.

In meditating on this problem I recalled a young man who in November 1942 lost the greater part of the tissues on the front of the forearm in a machine accident. After the usual treatment of the primary wound the raw area was covered with skin. A free graft from the ulnar nerve was used to bridge the large gap in the median; the wrist was fixed by arthrodesis and the extensors used to activate the digits (for details see Seddon 1947, Case S.63, page 161). This man made a good recovery and returned to work. He was far better off than the average patient with severe Volkmann's contracture. Why not then attempt to convert the arm damaged by ischaemia into something like one that had suffered a traumatic loss of substance? The idea seems simple enough but it took shape very slowly and the earlier operations were not very well conceived (see Tables $\mathrm{V}_{\mathrm{A}}$ and $\mathrm{B}$ ). At that time I was unaware that Massart (1935) had corrected a contracture by excision of the ischaemic muscle.

Case 7 was the first. The median nerve (Fig. 12) was successfully repaired by an ulnar nerve-pedicle graft (Strange 1947). But the contracture was dealt with only by division of tendons at the wrist, all the muscles being paralysed. I lacked either the wit or the courage 


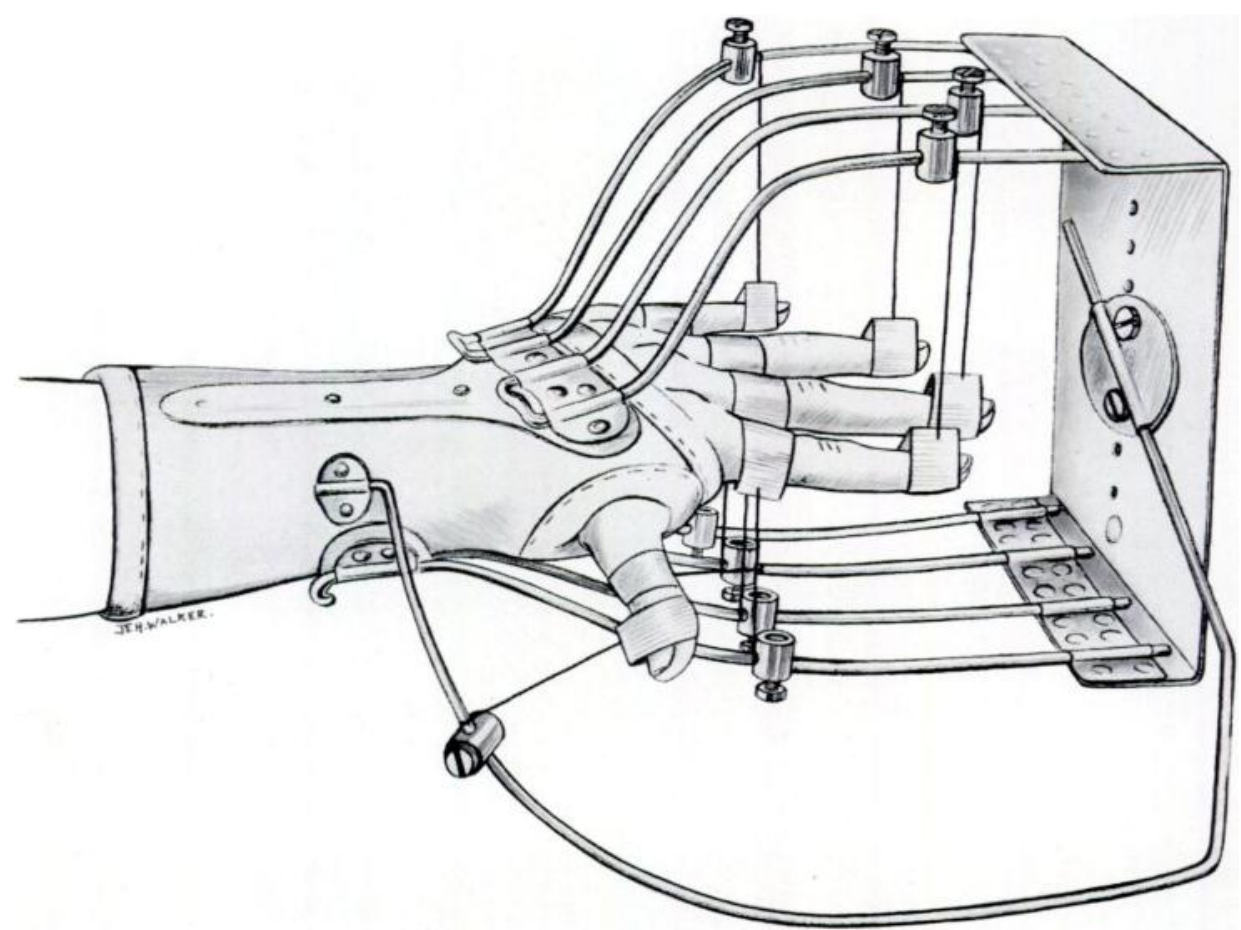

Fig. 14

The author's splint for the correction of moderate degrees of ischaemic contracture. The apparatus is cumbersome but has the merit of being removable; there is no risk of stiffness developing in any of the digital joints.

TABLE IV

A Summary of the Main features of Operations Commonly Used in the Treatment of Severe ISCHAEMIC CONTRACTURE

\begin{tabular}{|c|c|c|}
\hline Operation & Advantages & Disadvantages \\
\hline Muscle slide & $\begin{array}{l}\text { No interference with tendons } \\
\text { at level of the wrist }\end{array}$ & $\begin{array}{l}\text { Ineffective for paralysed muscles; } \\
\text { all flexor muscles are treated alike } \\
\text { irrespective of degree of damage. }\end{array}$ \\
\hline $\begin{array}{l}\text { Excision of proximal row } \\
\text { of carpal bones }\end{array}$ & $\begin{array}{l}\text { A minor operation; leaves soft } \\
\text { parts relatively undisturbed }\end{array}$ & $\begin{array}{l}\text { As for muscle slide; } \\
\text { only limited correction possible }\end{array}$ \\
\hline $\begin{array}{l}\text { Carpectomy-Griffiths (1940), } \\
\text { White and Stubbins (1944) }\end{array}$ & $\begin{array}{l}\text { A minor operation; leaves soft } \\
\text { parts relatively undisturbed }\end{array}$ & As for muscle slide; mutilating \\
\hline Bone shortening & $\begin{array}{l}\text { Leaves soft parts relatively } \\
\text { undisturbed }\end{array}$ & $\begin{array}{l}\text { Risk of non-union; ineffective for } \\
\text { paralysed muscles; all flexor muscles } \\
\text { treated alike irrespective of degree of } \\
\text { damage; extensors unduly slackened; } \\
\text { further shortening of an already } \\
\text { shortened forearm }\end{array}$ \\
\hline Arthrodesis of wrist & $\begin{array}{l}\text { Leaves soft parts relatively } \\
\text { undisturbed }\end{array}$ & $\begin{array}{l}\text { As for bone shortening, except that } \\
\text { there is no risk of non-union }\end{array}$ \\
\hline Tendon lengthening & Can be applied selectively & $\begin{array}{l}\text { Ineffective for paralysed muscles; } \\
\text { risk of tendons adhering to each other }\end{array}$ \\
\hline $\begin{array}{l}\text { Tenotomy of destroyed muscles } \\
\text { and tendon transplantation } \\
\text { (Parkes 1951) }\end{array}$ & $\begin{array}{l}\text { A rational operation and the } \\
\text { only one in this list which } \\
\text { aims at restoring power }\end{array}$ & $\begin{array}{l}\text { Risk of recurrence of the contracture } \\
\text { because the fibrotic and necrotic muscles } \\
\text { have only been tenotomised }\end{array}$ \\
\hline
\end{tabular}




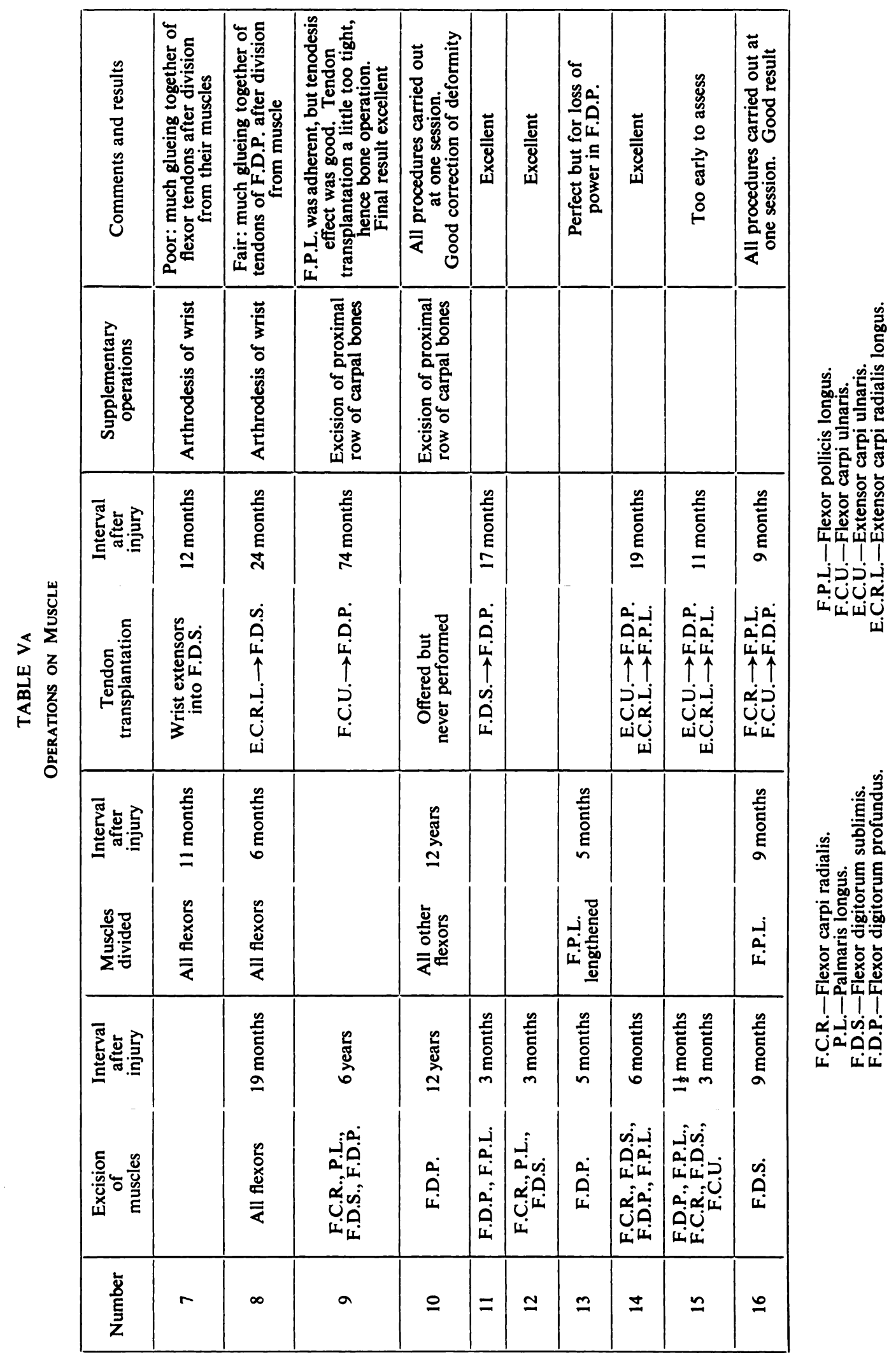

VOL. 38 B, NO. 1, FEBRUARY 1956 
TABLE VB

REPAIR OF NERVES

\begin{tabular}{|c|c|c|c|c|}
\hline $\begin{array}{c}\text { Case } \\
\text { number }\end{array}$ & Operation & $\begin{array}{l}\text { Interval } \\
\text { after injury } \\
\text { (months) }\end{array}$ & Comments & Results \\
\hline 7 & $\begin{array}{l}\text { Nerve pedicle: } \\
\text { ulnar to median }\end{array}$ & 8 and 10 & & $\begin{array}{l}\text { Thenar muscles very strong: pain and } \\
\text { light touch appreciated throughout } \\
\text { median area }\end{array}$ \\
\hline 8 & $\begin{array}{l}\text { Nerve pedicle: } \\
\text { ulnar to median }\end{array}$ & 8 and 12 & & $\begin{array}{l}\text { Thenar muscles very strong: pain and } \\
\text { light touch appreciated throughout } \\
\text { median area }\end{array}$ \\
\hline 14 & $\begin{array}{l}\text { Free graft: main } \\
\text { motor division of } \\
\text { median into median } \\
\text { in forearm }\end{array}$ & 6 & $\begin{array}{l}\text { Repair carried out } \\
\text { at same time as } \\
\text { excision of muscle: } \\
\text { mobilisation required } \\
\text { for approximation }\end{array}$ & $\begin{array}{l}\text { Thenar muscles strong except for } \\
\text { abductor which is still paralysed: } \\
\text { pain and coarse touch appreciated } \\
\text { throughout median area. Still time } \\
\text { for further recovery }\end{array}$ \\
\hline 15 & $\begin{array}{l}\text { Nerve pedicle: } \\
\text { ulnar to median }\end{array}$ & $1 \frac{1}{2}$ and 3 & $\begin{array}{l}\text { Repair carried out } \\
\text { at same time as } \\
\text { excision of muscle }\end{array}$ & $\begin{array}{l}\text { Recovering steadily but final } \\
\text { assessment not yet possible }\end{array}$ \\
\hline 16 & $\begin{array}{l}\text { Free graft: anterior } \\
\text { interosseous and medial } \\
\text { cutaneous of forearm } \\
\text { into median in forearm }\end{array}$ & 12 & $\begin{array}{l}\text { Mobilisation required } \\
\text { for approximation }\end{array}$ & $\begin{array}{l}\text { Recovering steadily but final } \\
\text { assessment not yet possible }\end{array}$ \\
\hline
\end{tabular}

to excise the ischaemic mass, and although a transplantation of the wrist extensors into the flexor tendons of the digits was performed, the result was disappointing. The tendons at the wrist became glued together, a consequence of the progressive foreign-body reaction round the ischaemic zone in the forearm.

Much the same procedure was followed in Case 8, though here I attempted to make amends by excising the ischaemic mass after simple division of the flexor tendons had failed. It was a little too late. The fibrotic process glued the tendons together at the wrist and the range of movement resulting from the subsequent tendon transplantation-though the power was good-was only one-fifth of the normal (see Fig. 15).

Case 9 was easier. There was no nerve lesion. Excision of the ischaemic muscle and tendon transplantation sufficed. Even at six years after the injury there was little fibrosis round the tendons at the wrist, perhaps because the ischaemia was more proximal than usual.

In Case 10 no operation was performed until twelve years after the injury. A calcified necrotic flexor digitorum profundus was excised, the tendons of the other fibrotic muscles being divided. Because there was a fixed bony deformity at the wrist the proximal row of the carpal bones was excised. There was severe nerve damage but it was too late to contemplate any sort of repair. The patient was so satisfied with the correction of the deformity that he has not yet agreed to submit to the tendon transplantation that should give him a still better hand.

In Case 11 (Fig. 16), treated by my colleague J. I. P. James, recovery was excellent; the operation was performed early and there was no serious nerve lesion. Case 12 (Fig. 17), treated by A. F. Rushforth, was unusual in that flexor sublimis digitorum suffered gross ischaemia whereas the deep flexors escaped. Apart from loss of the superficial flexor this child now has a normal hand. In Case 13 (Fig. 18) excision of the ischaemic deep flexors was performed early. The result was perfect apart from loss of power in the long flexor of the thumb and the deep flexors of the fingers. 


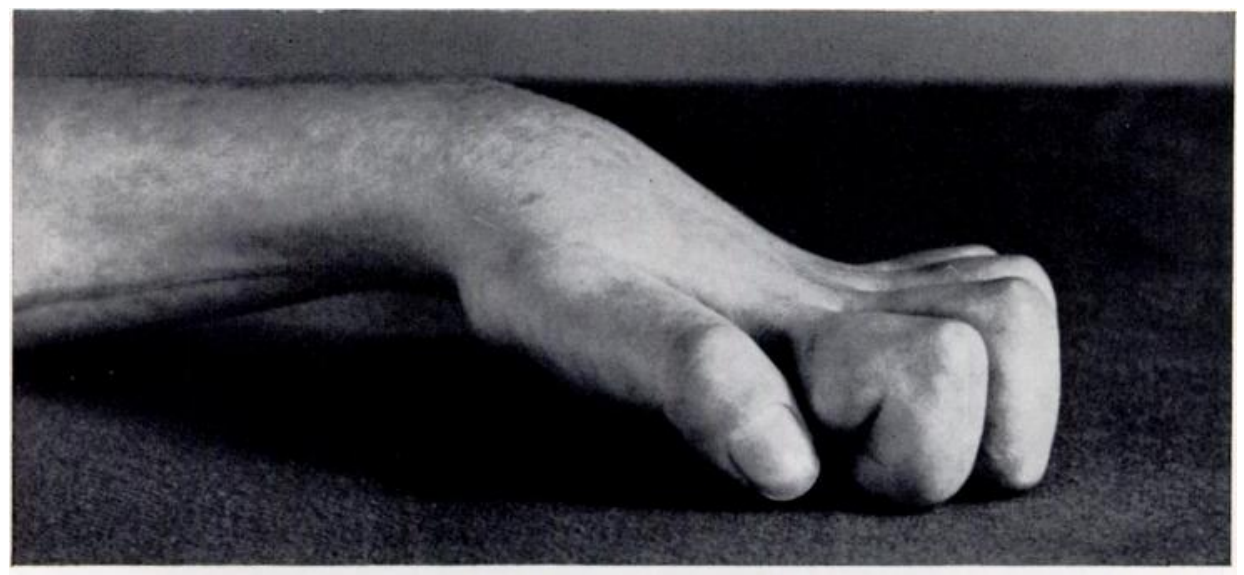

FIG. 15a

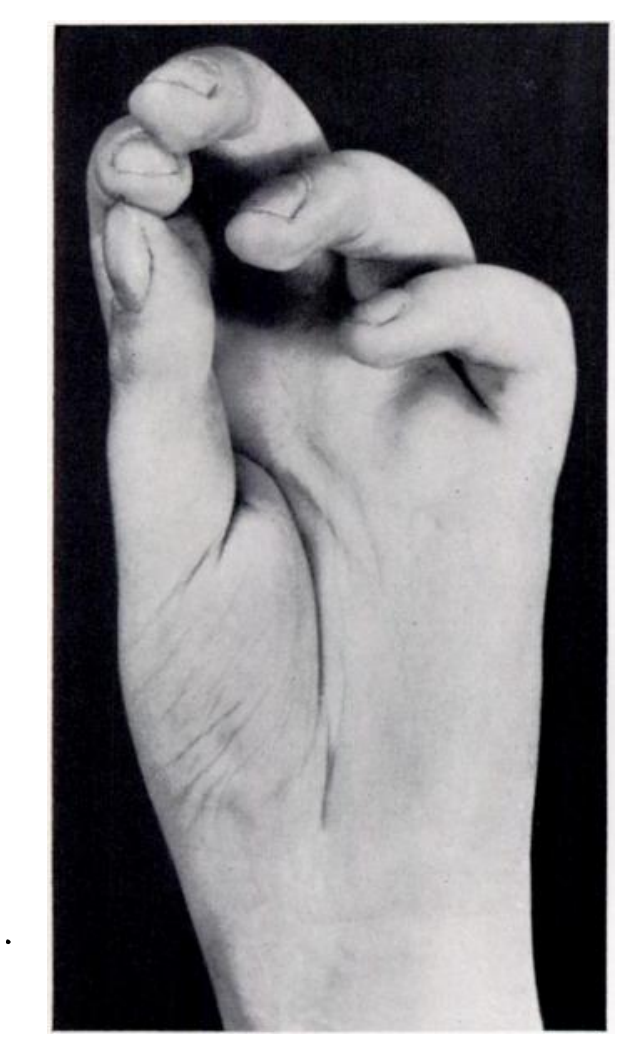

FIG. $15 b$

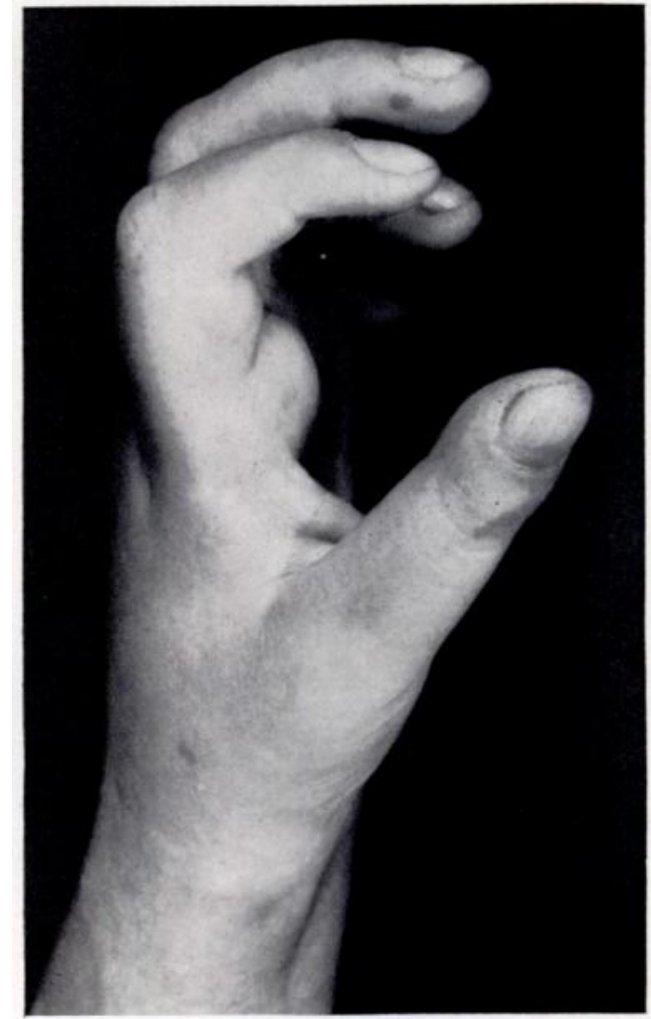

Fig. $15 c$

The result in Case 8. $a$-The hand before surgical reconstruction. $b$-After a nerve-pedicle graft the patient recovered good sensibility in the median area and strong power in the short muscles of the thumb which are shown opposing the thumb to the index finger. $c$-The hand is shown open. The range of movement was far short of normal but it was powerful and the patient was content. 


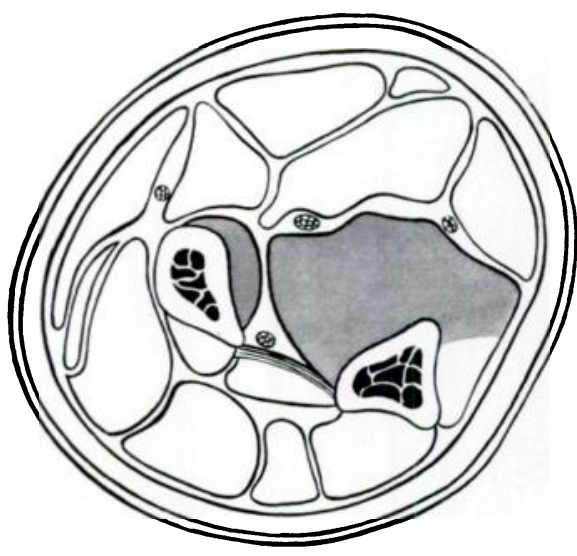

(a)
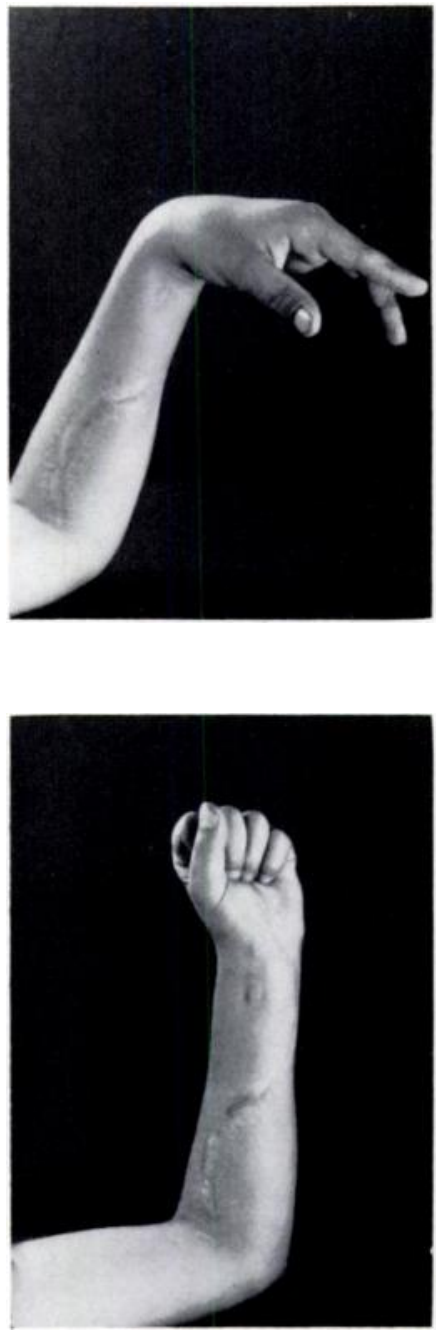

(c)

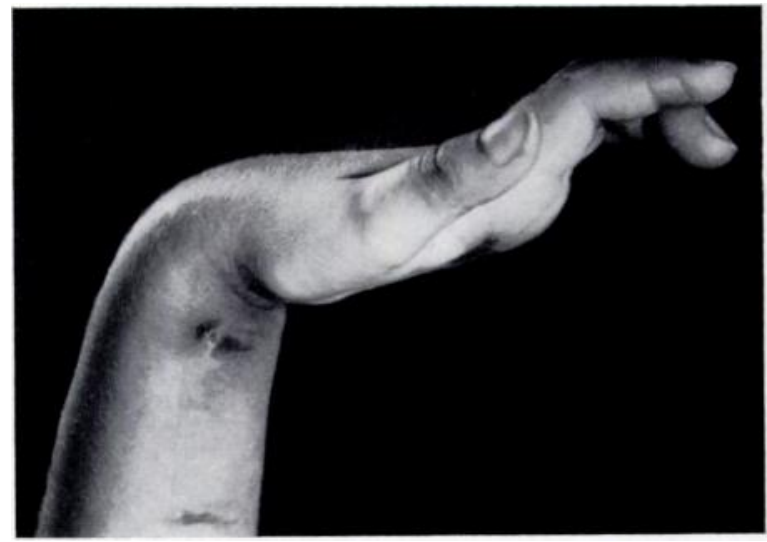

(b)
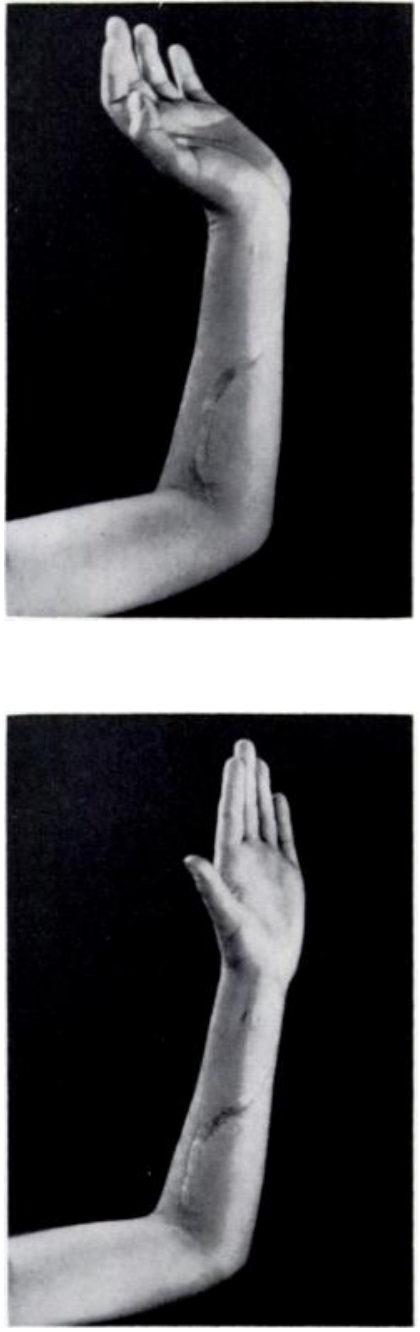

Figure 16. Case 11-Mr James's case. $a$-The muscle damage. $b$-The condition before operation. $c$-After operation. Function was perfect except for loss of power in the long flexor of the thumb. 


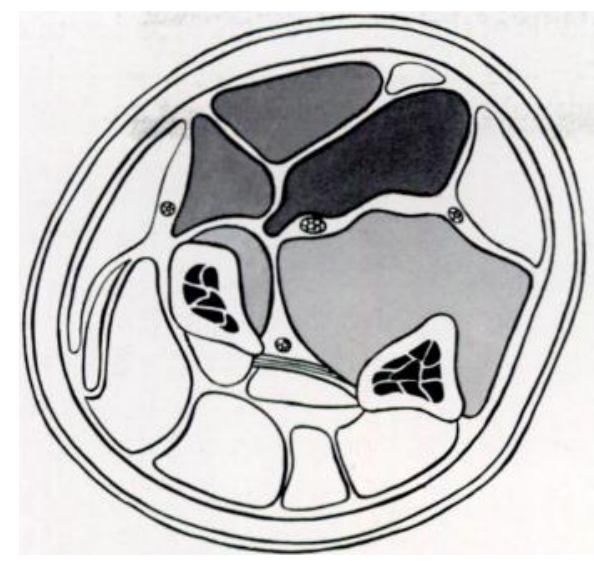

FIG. $17 a$

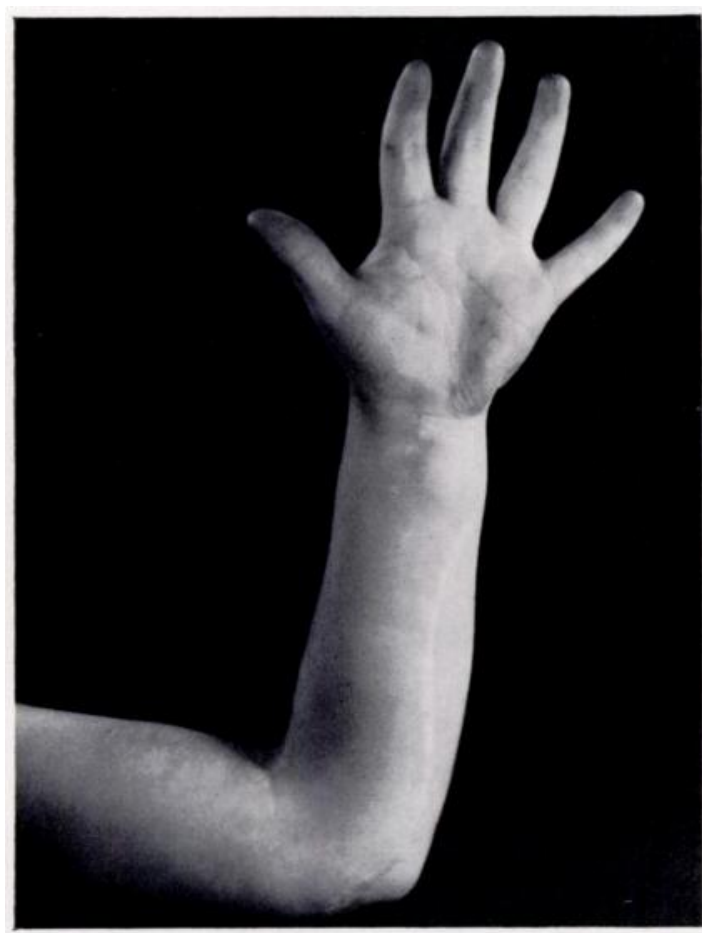

FIG. $17 b$

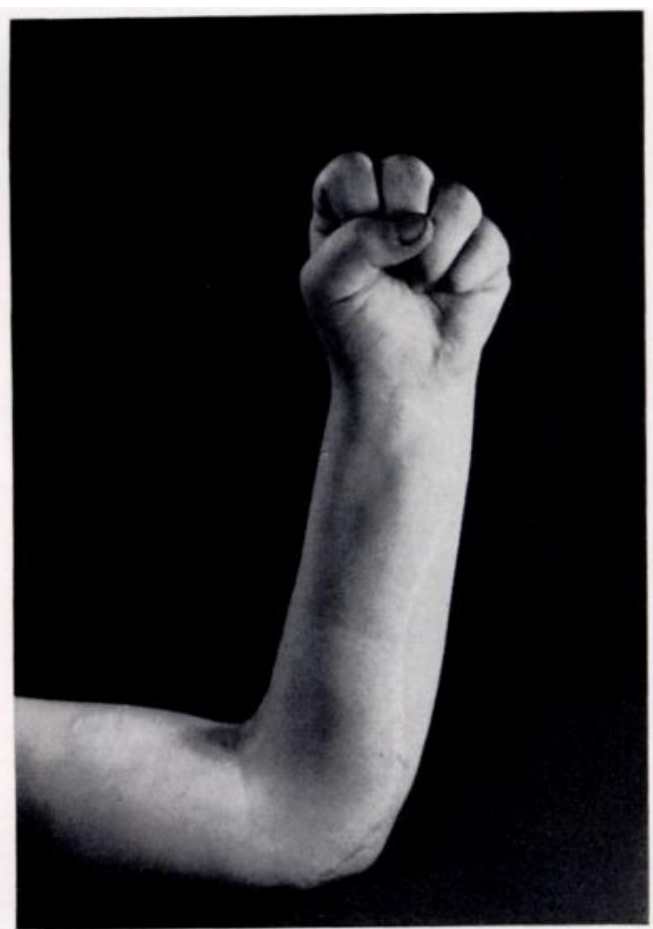

Fig. $17 c$

Case 12-Mr Rushforth's case. $a-$ Muscle damage. $b$ and $c$-Condition after operation. Function was perfect.

Of the remainder only Case 15 requires special mention. This patient, whose treatment is not yet concluded, came under my care five weeks after his injury. By this time the contracture was pronounced, there was a complete ischaemic lesion of both ulnar and median nerves, complete paralysis of all the long flexor muscles (Fig. 19) and considerable weakness of the extensors. I had been so impressed with the evil consequences of delay that I decided to explore the forearm six weeks after the injury, confident that I could recognise which structures were irreparably damaged. They were to be removed, the deformity would be immediately corrected, progressive fibrosis would be avoided and the reconstruction of muscles and nerves could begin forthwith. At operation the deep flexor muscles were found to be almost 
completely necrotic in the middle of their length (Fig. 20) and were excised. But I was uncertain about the superficial flexors-they were very shrunken, pale pink and shortened, and they contracted feebly only on powerful direct electrical stimulation. Were they irreparably damaged? It was too early to be certain. Fortunately there was no need to be disturbed about them because the ischaemia of the median nerve was extreme and extended well above the common flexor mass. There was clearly no hope for these muscles and the first stage of an ulnar to median nerve-pedicle graft was performed; but it might have been most awkward. Histological examination of these doubtful muscles did, in fact, reveal grave and irreversible changes. Yet, as it was, it was necessary to wait a year for recovery of the extensor muscles before using some of them for transplantation into the flexors of the digits.

It is therefore wrong to carry out this radical treatment within three months from the time of injury and it is probably wiser to wait six months.

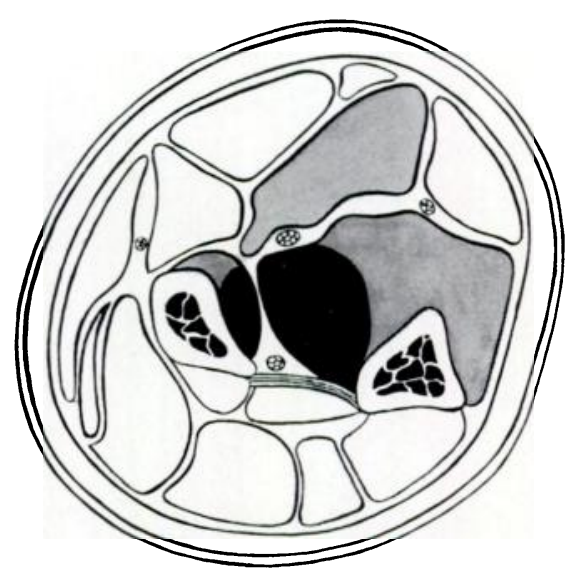

Fig. 18

Case 13-The circumscribed muscle damage.

\section{THE TECHNIQUE OF THE OPERATION}

The exposure and excision-The primary operation begins as a very extensive biopsy. The incision should be a longitudinal one in the mid-line of the forearm starting at the bend of the elbow and ending just above the wrist. Only in exceptional cases, such as Case 13 (Fig. 18) where the zone of ischaemia was very circumscribed, should a shorter incision be used. A bloodless field is essential during the first forty-five minutes but the pressure bag should then be released. It is useful to expose the median nerve at the bend of the elbow so that it can be stimulated directly and the contractility of the forearm muscles observed at intervals throughout the operation.

The superficial muscles are examined first. If they are necrotic they should be excised. If they are pale and fibrotic, and if they contract extremely feebly or not at all when the nerve is stimulated, they should be excised. In either case the dissection begins distally after identification of the median nerve, which must be traced proximally with the greatest care. However, certain muscles although shortened may contract well, in which case a decision must be made as to whether their tendons should be lengthened near the wrist or, if they are not flexors of the fingers, used for transplantation if all the finger flexors prove irreparably damaged. So they are best left alone until the state of the deep muscles has been determined.

The deep muscles are brought into view immediately when the superficial ones are excised. If the superficial muscles are to be preserved, then the deep ones are best exposed by an 


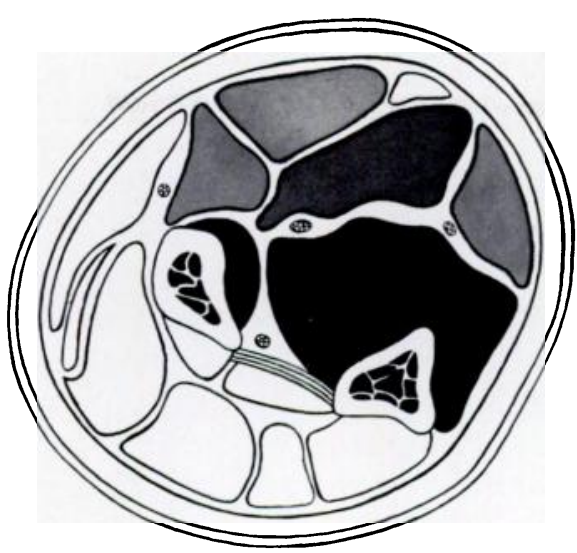

FIG. 19

Case 15-The muscle damage.

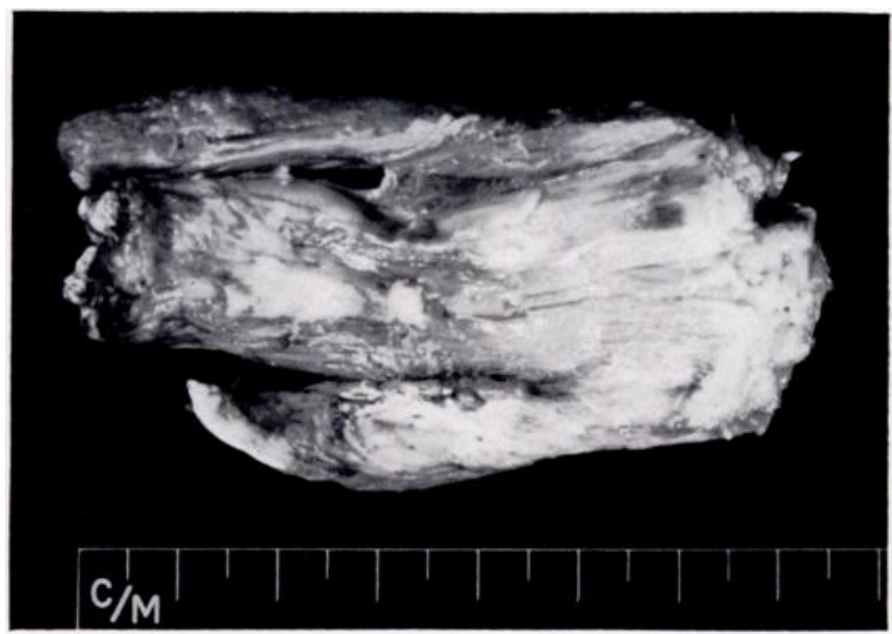

FIG. 20

Case 15-The excised mass of necrotic muscle, flexor digitorum profundus and flexor pollicis longus.

incision which again starts distally between the tendons of flexor carpi radialis and flexor digitorum sublimis. This exposure enables the surgeon to follow the median nerve proximally. More often than not the deep flexors of the fingers and the flexor pollicis longus are largely necrotic and should be excised en bloc from the point where the tendons make their appearance up to the junction-if there is one-of necrotic with healthy muscle. When the excision of these muscles has been completed, most if not all of the contracture of the digits will have been straightened out. The remainder of the contracture will disappear when the superficial muscles have been released. When both the superficial and the deep flexors of the fingers are hopelessly damaged, the tendons of the superficial flexors should be removed from the carpal tunnel; likewise if the superficial flexor alone is excised.

The surgeon now turns his attention to the nerves. If the ischaemia has been very severe it will be found that the median nerve narrows gradually from a point near the upper limit of the ischaemic zone until its diameter is about a quarter or a third of the normal. Its colour is greyish-yellow and if the tourniquet is released it will be found that this reach of the nerve is avascular. At the lower limit of the ischaemic zone the nerve gradually swells out again, 
but not to its normal diameter. Below the zone of ischaemia it has undergone ordinary Wallerian degeneration and has the appropriate diameter of about two-thirds of the normal.

The ulnar nerve is then inspected if there are signs of total interruption, but the degree of ischaemia is never as great as in the median. However, unless the diameter of the ulnar nerve and its colour and consistence are normal, it may safely be assumed that this nerve likewise has suffered irreparable damage. If the nerve appears and feels almost normal, it should of course be left alone.

Reconstructive procedures. a) Muscle-If the deep flexors alone require excision, surgical reconstruction is not essential. However in James's case (11) he aimed at and achieved a superb result by transplanting flexor digitorum sublimis into the tendinous remains of the deep flexor. The loss of flexion of the terminal phalanx of the thumb is relatively unimportant. If all the flexors of the digits have to be excised, then the surgeon must borrow what he can for transplantation into them. There may be a fairly powerful flexor carpi ulnaris (Case 16). Flexor carpi radialis is unlikely to be of any use where flexor digitorum sublimis has had to be removed. He may need to borrow one or more of the wrist extensors and here another problem arises. In a case of such severity it is possible, indeed likely, that the extensor muscles are feebler than normal. It is then wiser (Case 15) to wait a few months for the extensors to regain their strength before using them to activate the digits.

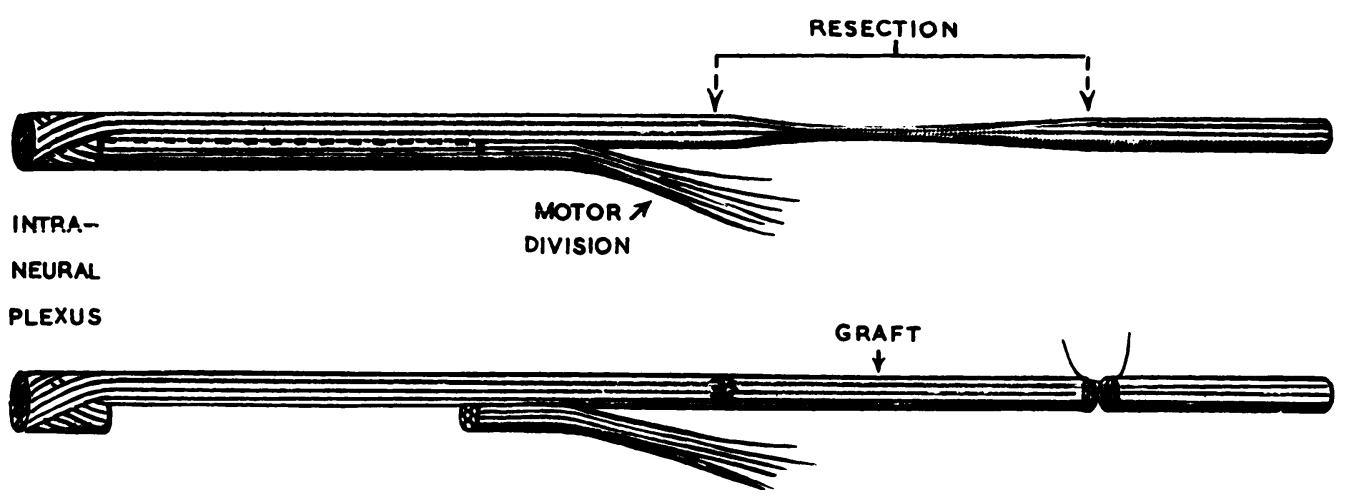

Fig. 21

A method of free grafting that can be used for repair of the median nerve in Volkmann's ischaemia. The intraneural plexus, above which dissection must not extend, is not visible on the surface as shown here but is easily apparent when the graft is being prepared. The graft should be about 15 per cent longer than the gap to be closed in order to allow for shrinkage. If it fits exactly the graft should be relaxed by flexion of the elbow.

b) The median nerve-If both the ulnar and median nerves have suffered severe ischaemia, a nerve-pedicle graft (Strange 1947) should be employed. There will of course be a permanent ulnar paralysis, but the quality of the recovery in the median has been so good in my three cases that this radical operation is fully justified.

Where the ulnar nerve appears healthy, the only possible solution is a free graft and the difficulty then is to find enough material. However, in such a case the gap to be bridged will not be very extensive, and on the two occasions (Cases 14 and 16) when free grafts were used sufficient material was found. There are two local sources of nerve grafts. The medial cutaneous nerve of the forearm will yield one and perhaps two strands if resected from the bend of the elbow up to the axillary fold. Although these grafts are long enough, their calibre is insufficient. One may then be compelled to employ also the motor division of the median itself when, as is likely, all the forearm flexors have been irreparably damaged (Fig. 21). The preparation of this graft calls for a delicate and tedious dissection. 
It will be seen from Table $\mathrm{V}$ that the nerve and tendon reconstructions have usually been carried out at different times, though one cannot generalise about which should come first.

Lastly, in a severe case, it may be necessary to perform an arthrodesis of the wrist if destruction of the flexors and borrowing extensors for activation of the flexors of the digits has caused loss of control of the wrist.

\section{RESULTS}

The results of repair of ischaemic nerves require little comment. The procedures used, although delicate, are technically straightforward and no mistakes were made in the five grafting operations that were performed. In three recovery has been exceptionally good; sensibility throughout the median area returned to the same extent as is seen after a satisfactory suture of the median nerve at the wrist, and the thenar muscles regained power little short of normal. In the other two cases final assessment is still not possible but recovery appears to be proceeding satisfactorily. Of the remaining five cases in which no repair was performed, there was one (Case 10) in which the lesion was of such long standing that nothing could be done. In another (Case 9) there was no evidence of nerve damage and in the other three recovery occurred spontaneously.

As has already been indicated the operations performed on muscles gave indifferent results in the earlier cases; this was before a more radical policy had been evolved. Where the tendons of hopelessly damaged muscles were simply divided there was a tendency for the deformity to recur, but in none has it done so to an extent that was crippling. All the patients were satisfied with their hands qua deformity. Where excision was performed early, as in Cases 11 to 16, correction of the deformity was very good and in four out of six cases complete. When excision was performed late, as in Cases 9 and 10, excision of the proximal row of the carpal bones was required as a supplementary operation.

The tendon transplantations need not be considered in detail. It is sufficient to say that in the seven cases in which they were performed the results were satisfactory except when the ischaemic muscles had been dealt with by simple tenotomy.

\section{SUMMARY}

1. In the common type of Volkmann's ischaemic contracture affecting the forearm flexors, the infarct takes the form of an ellipsoid with its axis in the line of the anterior interosseous artery and with its central point a little above the middle of the forearm. The greatest damage is at the centre and usually falls most heavily on flexor digitorum profundus and flexor pollicis longus, which are often necrotic. Those muscles more superficially placed, and sometimes the deep extensors, are more likely to exhibit fibrosis.

2. The median nerve runs near the centre of the ellipsoid and may exhibit profound ischaemia. The ulnar nerve, lying at the edge of the ischaemic zone, tends to be less severely affected.

3. The treatment for this condition is excision of all tissues irreparably damaged by ischaemia. If this operation is performed within twelve months from the time of injury, correction of the contracture should be almost complete. The tendons of shortened but active muscles are lengthened or transplanted.

4. After such excision it is possible to carry out reconstructive procedures commonly used in the surgery of lower motor neurone disorders and of trauma. A wide variety of tendon transplantations is available. The median nerve may be repaired either by a free graft or, in cases where both nerves have been extensively damaged by ischaemia, by an ulnar to median nerve-pedicle graft. 
Mr J. I. P. James and Mr A. F. Rushforth have generously allowed me to include Cases 11 and 12 respectively in this series. The histological work in all the recent cases has been carried out by Dr H. A. Sissons, Morbid Anatomist at the Institute of Orthopaedics, and I am grateful to him for his lively interest in this aspect of the work and for the excellent photomicrographs. Mr D. M. Brooks and I have carried out the various operations that were performed and he has contributed considerably to the evolution of the policy here recommended. Mr D. Lloyd Griffiths has been kind enough to read and criticise the manuscript.

Figures $3 a$ and $b, 16 a, 17 a, 18$ and 19 are based on Figure 315 in Angewandte und topographische Anatomie by G. Töndury, 1949, Georg Thieme Verlag, Stuttgart, for the use of which I am indebted to the author and publishers.

\section{REFERENCES}

BraSH, J. C. (1955): Neuro-vascular hila of limb muscles. Edinburgh and London: E. \& S. Livingstone Ltd. CahuzaC, M., and Jung, F. (1946): Le syndrome de Volkmann. Paris: Masson \& Cie.

Clark, W. E. Le Gros, and Blomfield, L. B. (1945): The Efficiency of Intramuscular Anastomoses, with Observations on the Regeneration of Devascularised Muscle. Journal of Anatomy, 79, 15.

Griffiths, D. Ll. (1940): Volkmann's Ischaemic Contracture. British Journal of Surgery, 28, 239.

Holmes, W., Highet, W. B., and Seddon, H. J. (1944): Ischaemic Nerve Lesions Occurring in Volkmann's Contracture. British Journal of Surgery, 32, 259.

HORN, J. S., and Sevitr, S. (1951): Ischaemic Necrosis and Regeneration of the Tibialis Anterior Muscle after Rupture of the Popliteal Artery. Journal of Bone and Joint Surgery, 33-B, 348.

Hughes, J. R. (1948): Ischaemic Necrosis of the Anterior Tibial Muscles due to Fatigue. Journal of Bone and Joint Surgery, 30-B, 581.

JACKSON, S. (1945): The Role of Galvanism in the Treatment of Denervated Voluntary Muscle in Man. Brain, 68, 300.

JACKSON, E. C. S., and SEDDON, H. J. (1945): Influence of Galvanic Stimulation on Muscle Atrophy Resulting from Denervation. British Medical Journal, ii, 485.

MASSART, R. (1935): La maladie de Volkmann. Revue d'Orthopédie, 3e série 22, 385.

Michel, L. (1924): L'utilisation des “ appareils à tourniquet " dans le redressement des rétractions ischémiques de Volkmann. Revue d'Orthopédie, 3, série 11, 349.

Parkes, A. (1951): The Treatment of Established Volkmann's Contracture by Tendon Transplantation. Journal of Bone and Joint Surgery, 33-B, 359.

Seddon, H. J. (1947): The Use of Autogenous Grafts for the Repair of Large Gaps in Peripheral Nerves. British Journal of Surgery, 35, 151.

Strange, F. G. St C. (1947): An Operation for Nerve Pedicle Grafting. British Journal of Surgery, $34,423$. White, J. W., and Stubbins, S. G. (1944): Carpectomy for Intractable Flexion Deformities of the Wrist. Journal of Bone and Joint Surgery, 26, 131. 